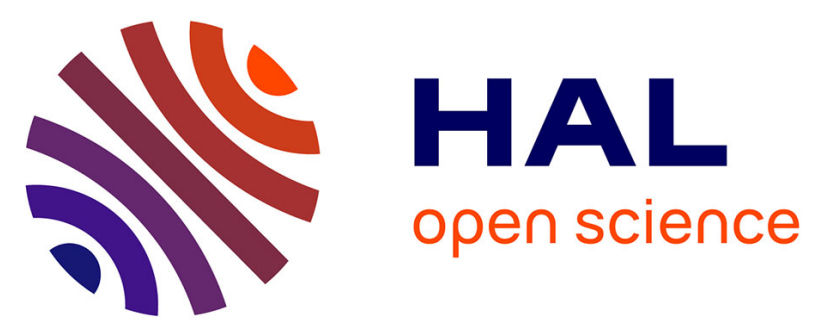

\title{
Missions to Mars: Characterization of Mars analogue rocks for the International Space Analogue Rockstore (ISAR)
}

Nicolas Bost, Francès Westall, Claire Ramboz, Frédéric Foucher, Derek Pullan, Alain Meunier, Sabine Petit, Iris Fleischer, Göstar Klingelhöferg, Jorge L. Vago

\section{To cite this version:}

Nicolas Bost, Francès Westall, Claire Ramboz, Frédéric Foucher, Derek Pullan, et al.. Missions to Mars: Characterization of Mars analogue rocks for the International Space Analogue Rockstore (ISAR). Planetary and Space Science, 2013, 82-83, pp.113-127. 10.1016/j.pss.2013.04.006 . insu00819716

\section{HAL Id: insu-00819716 https://hal-insu.archives-ouvertes.fr/insu-00819716}

Submitted on 22 May 2013

HAL is a multi-disciplinary open access archive for the deposit and dissemination of scientific research documents, whether they are published or not. The documents may come from teaching and research institutions in France or abroad, or from public or private research centers.
L'archive ouverte pluridisciplinaire HAL, est destinée au dépôt et à la diffusion de documents scientifiques de niveau recherche, publiés ou non, émanant des établissements d'enseignement et de recherche français ou étrangers, des laboratoires publics ou privés. 
Missions to Mars: Characterization of Mars analogue rocks for the International Space Analogue Rockstore (ISAR)

Nicolas Bost ${ }^{1,2,3,4, *}$, Frances Westall ${ }^{1}$, Claire Ramboz ${ }^{2,3,4}$, Frédéric Foucher ${ }^{1}$, Derek Pullan $^{5}$, Alain Meunier ${ }^{6}$, Sabine Petit ${ }^{6}$, Iris Fleischer ${ }^{7}$, Göstar Klingelhöfer ${ }^{7}$, and Jorge L. Vago ${ }^{8}$.

* Corresponding authors: bost.nicolas@orange.fr \& frances.westall@ cnrs-orleans.fr

${ }^{1}$ Centre de Biophysique Moléculaire, UPR CNRS 4301, 45071, Orléans, France

${ }^{2}$ Univ d’Orléans, ISTO, UMR 7327, 45071, Orléans, France

${ }^{3} \mathrm{CNRS} / \mathrm{INSU}$, ISTO, UMR 7327, 45071 Orléans, France

${ }^{4}$ BRGM, ISTO, UMR 7327, BP 36009, 45060 Orléans, France

${ }^{5}$ Space Research Centre, Department of Physics and Astronomy, University of Leicester,

Leicester LE1 7RH, United Kingdom

${ }^{6}$ Université de Poitiers, CNRS UMR 7285 IC2MP, 86022 Poitiers, France

${ }^{7}$ Institute of Inorganic and Analytical Chemistry, Johannes Gutenberg University Mainz,

Staudinger Weg 9, 55128 Mainz, Germany

${ }^{8}$ European Space Agency, Noordwijk, the Netherlands 


\section{Authors' affiliation addresses:}

\section{Nicolas Bost}

Centre de Biophysique Moléculaire, UPR CNRS 4301, Rue Charles Sadron, 45071 Orléans

Cedex 2, and Institut des Sciences de la Terre d'Orléans, UMR CNRS 6113, 1A Rue de la

Férollerie, 45071 Orléans Cedex 2

+33(0)677180140

bost.nicolas@orange.fr

\section{Frances Westall}

Centre de Biophysique Moléculaire, UPR CNRS 4301, Rue Charles Sadron, 45071 Orléans

Cedex 2,

+33(0)238257912

frances.westall@cnrs-orleans.fr

\section{Claire Ramboz}

Institut des Sciences de la Terre d'Orléans, UMR CNRS 6113, 1A Rue de la Férollerie, 45071 Orléans Cedex 2

+33(0)238255245

claire.ramboz@cnrs-orleans.fr

\section{Frédéric Foucher}

Centre de Biophysique Moléculaire, UPR CNRS 4301, Rue Charles Sadron, 45071 Orléans Cedex 2,

+33(0)238257641

frederic.foucher@cnrs-orleans.fr

\section{Derek Pullan}

Space Research Centre, Department of Physics and Astronomy, University of Leicester, Leicester LE1 7RH, United Kingdom

$+44(0) 1162523794$

derek.pullan@le.ac.uk

\section{Alain Meunier}

Université de Poitiers, CNRS UMR 7285 IC2MP, HydrASA, B35 rue Michel Brunet, 86022

Poitiers Cedex, France

+33(0)549453734

alain.meunier@univ-poitiers.fr

\section{Sabine Petit}

Université de Poitiers, CNRS UMR 7285 IC2MP, HydrASA, B35 rue Michel Brunet, 86022 Poitiers Cedex, France

+33(0)549453756

sabine.petit@univ-poitiers.fr

\section{Iris Fleischer}

Institute of Inorganic and Analytical Chemistry, Johannes Gutenberg University Mainz, Staudinger Weg 9, 55128 Mainz, Germany

$+49(0) 6131-3920852$

fleischi@uni-mainz.de 


\section{Göstar Klingelhöfer}

Institute of Inorganic and Analytical Chemistry, Johannes Gutenberg University Mainz, Staudinger Weg 9, 55128 Mainz, Germany

+49613139-23282

klingel@uni-mainz.de

\section{Jorge L.Vago}

European Space Agency, ESA/ESTEC (SRE_SM), Keplerlaan 1, 2200 AG Noordwijk, the Netherlands.

+31715655211

jorge.vago@esa.int 


\section{Abstract}

Instruments for surface missions to extraterrestrial bodies should be cross-calibrated using a common suite of relevant materials. Such work is necessary to improve instrument performance and aids in the interpretation of in-situ measurements. At the CNRS campus in Orléans, the Observatoire des Sciences de l'Univers en région Centre (OSUC) has created a collection of well-characterised rocks and minerals for testing and calibrating instruments to be flown in space missions. The characteristics of the analogue materials are documented in an accompanying online database. In view of the recent and upcoming rover missions to Mars (NASA’s 2011 Mars Science Laboratory (MSL) and ESA/Roscosmos’2018 ExoMars), we are concentrating initially on materials of direct relevance to the red planet. The initial collection consists of 15 well-studied rock and mineral samples, including a variety of basalts (ultramafic, weathered, silicified, primitive), sediments (volcanic sands, chert, and a banded iron formation -BIF-), and the phyllosilicate nontronite (a clay). All the samples were characterised petrographically, petrologically, and geochemically using the types of analyses likely to be performed during in-situ missions, in particular ExoMars: hand specimen description; optical microscopy; mineralogical analysis by XRD, Raman and IR spectrometry; iron phase analysis by Mössbauer spectroscopy (MBS), elemental analysis by EnergyDispersive X-ray spectroscopy (EDX), microprobe, Inductively Coupled Plasma Atomic Emission Spectrometry (ICP-AES) and Mass Spectrometry (ICP-MS); and reduced carbon analysis by Raman spectrometry.

\section{Key points}

Mars; Mineralogy; Experimental techniques; Database; Astrobiology. 


\section{Introduction}

\subsection{General context}

This first collection of extraterrestrial-analogue materials is primarily oriented towards the on-going and future Mars missions, in particular NASA's Mars Science Laboratory (MSL) Curiosity rover, which landed in August 2012, and the future European ExoMars rover (with international partners), to be launched in 2018. The science objectives of the two missions overlap: investigating the habitability of surface environments within the landing ellipse, the potential of materials therein for preserving traces of life, and the search for any trace of past and, in the case of ExoMars, present life. More generally, these missions will study the geological diversity of the Martian surface. It is this aspect which we address in the following study.

Each mission will benefit from a suite of complementary instrumentation that allows long-range to close-up observation and analysis of outcrops and materials obtained from the surface and the subsurface (Table 1). Arm mounted pencil drills will obtain outcrop samples for Curiosity and, on the ExoMars mission, a drill will collect subsurface material for analysis down to depths of $2 \mathrm{~m}$, where organic molecules could be preserved from surface destruction due to weathering, oxidation, perchlorates, UV radiation and ionizing radiation (e.g. Bullock et al., 1994; Stoker and Bullock, 1997; Kminek and Bada, 2006 and references therein). Cameras and microscopes will be used to study the context and gather crucial rock structural and textural information. For mineralogy, Curiosity includes an X-Ray Diffractometer (XRD) working on pulverized samples. On ExoMars, the bulk mineralogy information of surface lying materials will be established using a mast IR spectrometer. Once samples are collected, a VIS-IR imaging spectrometer and a Raman spectrometer will provide a more complete mineralogical description. On Curiosity, the elemental composition of 
samples is determined using a mast-mounted Laser-Induced Breakdown Spectrometer (LIBS), an arm Alpha Particle X-ray Spectrometer (APXS), and X-Ray Fluorescence (XRF). For the analysis of organic molecules Curiosity has a Thermal Volatilization, Gas Chromatograph, quadrupole Mass Spectrometer (TV-GCMS) instrument, including a Tunable Laser Spectrometer (TLS) for gas analyses. ExoMars will perform a very complete characterisation of organic molecules, using a combination of Laser Desorption, ion-trap mass spectrometry with thermal volatilisation gas chromatography mass spectrometry, including a variety of derivatisation agents (LDMS+TV-Der GCMS).

Due to the very limited availability of Martian materials (there are only 67 known meteorites from Mars), analogue samples are necessary to cross-calibrate these space instruments, especially if the analysis techniques are destructive. As a contribution to the preparation of the future missions to Mars and other planet/asteroid bodies, a rockstore (or lithothèque), here termed the International Space Analogue Rockstore (ISAR), has been created in Orléans (France) under the auspices of the Observatoire des Sciences de l'Univers en région Centre (OSUC). The objective of the ISAR is to provide a collection of analogue rocks and minerals that are well characterised by standard laboratory instrumentation. Some ISAR samples are already being used to calibrate and test the ExoMars Pasteur payload instruments (Table 1). The rockstore also includes an online database detailing all the textural, structural and compositional characteristics of the rock collection (http://www.isar.cnrsorleans.fr).

Based on the information obtained from in situ analyses made during the Pathfinder and MER missions, laboratory analyses of Martian meteorites, orbital spectral data from the surface, and the present knowledge of the primitive Earth and Archaean rocks (formed on similar environments to Mars), a first suite of representative rocks has been characterised. These analogue samples were selected for their relevance in terms of petrography and 
mineralogy. However, the organic component of the rocks has not been addressed at this time (but will be in the futures), Archaean rocks containing primitives traces of life form part of the collection because of their relevance for potential Martian microbial remains. In the following we present a preliminary, representative selection of rocks from the ISAR collection that now contains more than 50 specimens.

\subsection{The ISAR project}

\subsubsection{Background}

The ISAR is inspired by, and is a continuation of, a project first initiated in 2002 called the Geological Specimen Archive, or GSPARC (Pullan, 2008). The GSPARC was an integrated archive/database of physical samples and experimental data designed around a unique organising principle. GSPARC was populated with mostly "generic" (terrestrial) samples sorted by color, texture, fabric, composition, physical state and size. The idea was to provide samples for imaging, analytical and geotechnical research and instrument characterisation/development. Only some of the samples were planetary analogues. In contrast, all rocks and minerals included in the ISAR collection were specifically selected for their similarity with space bodies in terms of mineralogy, petrology and geochemistry. There are a number of collections that are designed to test individual instruments during their development. However, they are not readily available to the space community at large. Conversely, it has been the intention from the very beginning that the ISAR collection be open to the entire scientific community for the preparation of space instruments (www.isar.cnrs-orleans.fr).

\subsubsection{Sample collection and preparation methods}


The ISAR samples have been observed and analysed in a number of formats. At the outcrop and hand specimen scale, rough rock surfaces of freshly collected samples and/or of sawn rock samples were used. Rock fragments exhibiting both weathered and fresh surfaces were used for Mössbauer spectrometry (MBS). Powdered rock samples (<100 $\mu \mathrm{m}$ grain size) were prepared with an electrical and then a manual agate mortar for Raman spectroscopy, infrared spectroscopy (IR), X-Ray Diffraction (XRD), and Inductively Coupled Plasma (ICP) analysis. Sieved powders with a grain size $<250 \mu \mathrm{m}$ were also prepared because this is the mean particle size of the powder produced by the Sample Preparation and Distribution System (SPDS) of the ExoMars rover mission. Finally, standard polished thin sections $(30 \mu \mathrm{m}$ thick) were also prepared at CNRS-ISTO-Orléans laboratory for high quality optical microscopy, Raman spectroscopy, cathodoluminescence, Scanning Electron Microscope (SEM), Energy-Dispersive X-ray spectroscopy (EDX), and electron microprobe studies. These last, thin-section procedures were undertaken because they are part of the standard methods of rock analysis, even though this type of sample preparation is not available on the MSL or ExoMars missions.

The nomenclature used to arrange the samples takes into account the heredity and the relationship between them. Two types of samples were defined: the initial parent samples and the sub-samples. The initial parent samples correspond to those taken in the field. They can be seen as "a box" containing all the pieces of same nature, originating from one place and obtained at a given time. They may be composed of several fragments of rocks, sand, gravel, etc. The name of the initial samples consists of two numbers for the year, two letters for the originating country/locality (after ISO 3166-1 alpha 2 standard) and two numbers for the order of sampling during the fieldtrip. For example 10ZA02 is the second sample taken in 2010 in South Africa. Some parts of the initial samples are then crushed in powder or prepared as thin sections. These processed samples are labelled by adding a dash and a 
number to the name of the initial sample, for example 10ZA02-1. The cutting waste is not referenced and is replaced back in the box of the initial sample. Finally, samples can also be split into subsamples. These subsamples are then named by adding a letter at the end of the original sample reference. They can themselves be further split and the additional subsamples will be named by adding a number at the end: 10ZA02-1a then 10ZA02-1a1...

\subsection{Martian geology}

\subsubsection{General points}

Although the Earth and Mars formed at the same time ( 4.5 Gy) by a similar process and, from the point of view of microbial habitability, the environmental conditions in their early history were somewhat comparable (Westall, 2005), their subsequent evolutions were very different. Crustal recycling by plate tectonics may have initiated relatively early in the history of the Earth, as shown by the 3.8 Gy-old Isua formation in Greenland (e.g. Komiya et al., 1999). On the contrary, there is no irrefutable evidence of such activity on Mars, even in its youngest history (Carr and Head, 2009; Holt et al., 2010). Moreover, all major geological activity on Mars ceased at about 2.5 Gy, although sporadic volcanism continued thereafter (see Carr and Head, 2009; Anderson et al., 2001).

Some insight into the inner structure of Mars has be deduced from the mass of the planet, its moment of inertia, gravity field, topography, surface rock chemistry, and by modelling (Breuer et al., 2010). In particular, it has been shown that the Martian mantle is denser than that of the Earth due to the higher Fe-content. Analyses of the SNC meteorites suggest that they originated from four types of mantle reservoirs: Light Rare Earth Elements(LREE)-enriched, two LREE-depleted and a primordial reservoir that formed rapidly within the $10 \mathrm{My}$ of planet consolidation and that these mantle reservoirs did not mix (Wadwha and Borg, 2006; Papike et al., 2009). The Martian crust is very thick, representing $>4 \%$ of the volume of the planet (compared to only $1 \%$ for the Earth). It was constructed by 
igneous processes and modified by hydrothermal alteration, weathering, and sedimentary processes (Taylor et al., 2008). The composition of the Martian surface has been determined from analysis of Martian meteorites, spectral observations from orbit (e.g. Mars Express, MRO), and from surface rover analysis (Sojourner, Spirit and Opportunity). Based on these data, Mars is viewed as being dominantly basaltic, consisting mainly of tholeites and highly weathered basalts formed by partial mantle melting (McSween et al., 2009). Most of the Martian surface is covered by many meters of regolith.

\subsubsection{Volcanic rocks}

NASA’s Mars Global Surveyor (MGS) Gamma Ray Spectrometer (GRS) and Mars Odyssey Thermal Emission Spectrometer (TES) provided the first direct information on the average composition of the Martian crust. Subsequently the Mars Pathfinder mission detected rocks having an andesitic composition at the landing site (Chryse Planitia in Ares Vallis; e.g. Wänke et al., 2001). More recently, these rocks were re-interpreted as basalts whose surfaces had been altered (Bandfield et al., 2004; Christensen et al., 2005; Wyatt and McSween, 2002; Michalski et al., 2005). The initial interpretation was erroneous because it was carried out on the altered surfaces of the rocks. In contrast, analyses made during the later MER missions were obtained from "cleaned" rock surfaces prepared with a Rock Abrasion Tool (RAT). The Spirit rover provided extensive in-situ analyses of basaltic rocks and soils from the Gusev crater (e.g. Gellert et al., 2004). The chemistry of Martian volcanic rocks from the basalttephrite-basanite-picrobasalt-komatiite tholeitic suite is commonly evaluated by reference to the total alkali-silica (TAS) and the $\mathrm{FeO} * \mathrm{MgO}$-silica classification diagrams shown in Fig.1 (modified after McSween et al., 2009 and Le Bas et al., 2000). Most in-situ analyses of rocks from the Martian surface plot in the silica-poor side of the basaltic field, with rare tephrite samples overlapping the picrobasalt field of the TAS diagram (green and blue dots in Fig. 1a). 
Note that young Martian meteorites (shergottites) plot outside the basaltic field and are therefore not representative of the crust (McSween et al., 2009). The basaltic composition of the Adirondack, Humphrey and Mazatzal rocks from Gusev crater was analysed by Gellert et al. (2004) and McSween et al. (2004). The composition of these basalts is interpreted in terms of normative anorthite, fayalite, forsterite, diopside, hypersthene and some chromite, magnetite, ilmenite and apatite. Gellert et al. (2006) suggested that the Gusev rocks were similar to terrestrial basalts although they contain higher contents of $\mathrm{MgO}$ (8wt\% to $10 \mathrm{wt} \%$ ), $\mathrm{FeO}$ (15 to $18 \mathrm{wt} \%)$ and $\mathrm{Cl}(>0.70 \mathrm{wt} \%)$. In this study, we used the in-situ analyses of Gusev Martian basalts in order to evaluate the degree of analogy of the terrestrial basaltic materials selected for the ISAR. Compositions of the terrestrial basalts selected are plotted in Fig.1. As typical terrestrial basalts, they are depleted in Fe and Mg compare to Martian basalts (Fig. 1b). However, the MSL mission has recently observed volcanic rocks in the Gusev crater, in particular "Jake Matijevic", having a silica and alkali-rich composition similar to mugearite (Stolper et al., 2013; Fig 1).

\subsubsection{Sedimentary rocks and minerals}

Although they are less abundant than basalts, sedimentary rocks do occur on Mars. For instance, the Meridiani Planum outcrops show evidence of opaline silica, sulphates, clays, hematite, and evaporites, as analysed by the MER Opportunity (e.g. Reider et al., 2009; McLennan et al., 2005; Glotch et al., 2006). There are also derivatives from basaltic precursors, i.e. basaltic sands, altered sands and volcanics (Tosca et al., 2004; Ehlmann et al., 2009). The alteration of these materials may be related to water and/or hydrothermal fluids (e.g. Bibring et al., 2006; Ehlmann et al., 2009; 2010; Viles et al., 2010). Orbital spectral analyses, for example, suggest aqueous alteration of the surface materials first by neutral to alkaline fluids during the pre-Noachian/Noachian period, followed by alteration under more 
acidic conditions from the Hesperian onwards (Poulet et al., 2005; Bibring et al., 2006). The different alteration stages resulted in the formation of phyllosilicates, such as Fe-Mg smectites (saponite, nontronite) in the first period, and Al-rich smectites under the later, more acidic conditions. Although phyllosilicates can be formed by deuteric processes, in particular during fractionation within the magmatic chamber (Meunier al., 2010; 2012), aqueous alteration of rocks is the most commonly proposed formation process to explain the presence of phyllosilicate occurrences on Mars (e.g. Poulet et al., 2005; Bibring et al., 2006; Ehlmann et al., 2009; 2010; Viles et al., 2010). The interest of such rocks for the search for traces of life is that aqueous-altered volcanic rocks could indicate potential ancient habitable conditions.

Alteration and silica-enrichment due to hydrothermal activity have also been detected in laminated and cross-bedded tephra in the Eastern Valley between Home Plate and Mitcheltree/ Low Ridge complex (Squyres et al., 2008). Ruff et al. (2011) suggest that the opaline silica identified could be interpreted as hot spring sinter deposits associated with volcanic activity. Silica deposits are visible in the Martian surface and form elongated dykes (Ruff et al., 2011) or nodules (Squyres et al., 2008). Miliken et al. (2008) suggest that these deposits formed during Hesperian to Amazonian time. On Earth, the precipitation of hydrothermal silica favours the preservation of traces of fossil life in volcanic sediments (Westall et al., 2006a; 2006b; 2011a; 2011b). Recent observations also suggest evidence of diagenetic quartz in the Noachian Antoniadi crater (Smith and Bandfield, 2012).

Carbonates have also been detected from orbit and in situ on Mars (Ehlmann et al., 2008; Boynton et al., 2009; Michalski and Niles, 2010; Morris et al., 2010). Secondary carbonates also occur in SNC meteorites. For example, zoned Fe and Mg carbonate phases, dated at 3.9 Gy (Borg et al., 1999; Treiman et al., 2002), occur in the 4.5 Gy-old ALH84001 meteorite. In the Comanche outcrop in Gusev Crater, Fe-Mg-rich carbonates were formed by 
alteration of basalts (Morris et al., 2010). Calcium carbonate was also detected at 3-5 wt\% in the Martian polar soils during the Phoenix mission (Boynton et al., 2009).

Finally, recent observations from the MSL mission detected "conglomerates" at the Bradbury landing site, Goulburn, Link and Hottah exposures. These "conglomerates" contain rounded pebbles associated with uncemented gravels (Grotzinger et al., 2013).

\section{Methods}

Our methodological approach to the analysis of the ISAR samples is mainly based on the investigation strategy of the MSL and ExoMars missions, and takes into account the instrumentation on the rovers. The list of instruments on Curiosity and on the 2018 ExoMars rover is given in Table 1. Optical observations will be available on rocky outcrops and fresh drill cores but most of the analyses will be made on powdered samples. Note that our laboratory sample preparation, observations and analyses were more extensive than those made by in situ rovers. The samples were observed and analysed in a number of formats: at the outcrop and hand specimen scale, rough rock surfaces of freshly collected samples, sawn rock samples surfaces, powders and thin sections. We used additional methods of analysis to those that will be used in the MSL and ExoMars missions, including optical microscopy and Raman spectrometry on thin sections, scanning electron microscopy (SEM) with EDX, cathodoluminescence, electron microprobe, and ICP-OES/MS. Moreover, certain samples, such as 00AU05 (a microfossil-containing in silicified volcanic sands from the Pilbara, Australia) were submitted to more detailed analyses pertaining to investigations of traces of past life (Westall et al., 2006a; 2011a).

The photographs of the outcrops and samples were made with an Olympus E410 camera using different objectives. The thin sections were observed with a microscope Olympus BX51 in transmitted, reflected and polarized light. Various SEMs were used: a JSM- 6400 JEOL coupled with an EDX analysis at ISTO, Orléans, and a Hitachi FEG-SEM 
S4200 at the University of Orléans. Raman spectroscopy was made using a WITec Alpha500RA Raman spectrometer (CBM-Orléans) with a frequency doubled Nd:YAG green laser at $532 \mathrm{~nm}$, similar to that used for the ExoMars mission (Rull-Pérez and Martinez-Frias, 2006). IR spectra were acquired in transmitted mode in the in 400-4000 $\mathrm{nm}$ range using a Nicolet spectrometer (ISTO-Orléans) and with a Nicolet Magna IR 760 spectrometer ESP associated with a Thermo Scientific Integrations Sphere near IR Nicolet 6700 FT-IR (IC2MP, University of Poitiers). X-ray diffraction patterns were acquired using an INEL XRM3000/CPS120 diffractometer in transmitted mode. Powders were analysed in a $0.3 \mathrm{~mm}$ wide capillary using a $\lambda \mathrm{K} \alpha$ beam emitted by a Co generator. The acquisition time was variable depending upon the sample (ISTO-Orléans). Mössbauer spectra were acquired with a laboratory version of the miniaturized spectrometer "MIMOS II" that is also part of the payload of the two MERs (Klingelhöfer et al., 2003). Spectra were obtained in backscattered geometry with a field of view of $15 \mathrm{~mm}$ at the Johannes Gutenberg Universität-Mainz. Elemental analyses were made on rock powders using ICP-OES/MS in the Service d'Analyse des Roches et Minéraux - Centre de Recherches Pétrographiques et Géochimiques (SARMCRPG), Nancy, France. Finally, the elemental compositions of specific minerals were analysed using a Cameca SX-50 electron microprobe at ISTO-BRGM-Orléans. Obviously, the acquisition parameters were defined and adapted for each sample. This information is available via the ISAR website (www.isar.cnrs-orleans.fr).

\section{Materials and results.}

The list of the characterized samples is given in Table 2. They are shown in Fig. 2 and Fig.3.

\subsection{Volcanic rocks}




\subsubsection{IT01, "primitive" basalt}

Sample 09IT01 comes from the Etna volcano (N 37749924, E 15027535), Sicily, Italia. It was provided by Sylvio Roto (University of Palermo, Italy). Etna is a basaltic stratovolcano well known for its frequent effusive eruptions. Although the lavas are compositionally picritic, the sample 09IT01 comes from one particular horizon of Etna lavas characterised by a "primitive", non-fractionated composition (Coltelli et al., 2005). "Primitive" lavas are rare on Earth but must be common on Mars.

The observations and analyses showed that the sample is a micro-vesiculated tephra composed of olivine-rich scoria lapilli and rare cognate lithic clasts (Fig. 2a). Large olivine grains (1-2 mm) are present (Fig. 2b). Mineralogically, the rock consists of large blocky olivine crystals $\left(\mathrm{Fo}_{91}\right)$ and smaller euhedral olivine associated with pyroxenes (diopside, $\mathrm{Mg}_{\# 92.5}$ ) in a basaltic glass (Fig. 2b). Some small plagioclase crystals occur in the pyroxene matrix. The basalt contains some $\mathrm{Cr}$-spinel grains. The chemical composition of each mineral is given in Table 3.

Sample 09IT01 is a good geochemical analogue of Martian basalt; it falls at the limit of the main Martian basalt field both in the TAS and $\mathrm{FeO} * / \mathrm{MgO}$ versus silica diagrams (Fig. $1)$.

\subsubsection{SJ15, tephritic basalt}

This "tephritic-basalt" was sampled in the Sverrefjell quaternary stratovolcanoes, (N 79437583, E $13^{\circ} 341433$ ) on Svarlbard (Norway), during the AMASE 2009 Mission. It was formed by off-ridge alkali basaltic volcanism associated with the opening of the Arctic Basin and the Greenland Sea (Skelkvåle et al., 1989), which yielded primitive and ultramafic basalts containing approximately $20 \%$ xenoliths (mantle dunites, sample 09SJ02, see section 3.2, and 
some gneissic crustal elements; Fig. 2c). This volcanism is subactive and associated with hot springs.

Sample 09SJ15 is a massive and highly vesicular basalt (vesicle sizes ranging between 1 to $5 \mathrm{~mm}$; Fig. 2c). Dunite xenoliths up to $2 \mathrm{~cm}$ in size and some macroscopic olivine grains (0,5-1 mm size) can be observed in the basalt (Fig. 2c). The mineralogy of the primitive basalt is olivine $\left(\mathrm{Fo}_{90}\right)$ occurring as phenocrysts with pyroxenes $\left(\mathrm{Mg}_{\# 57}\right)$ associated with plagioclase microlites, spinels and minor glass (Fig. 2d). The chemical composition of these three major silicate phases is given in Table 3. Secondary minerals include amphibole and oxides. This sample has the particularity of containing quartz grains, certainly of xenolithic origin.

Sample 09SJ15 has a chemical composition which is relevant for tephritic Martian basalts, rich in alkali elements. Its textural and mineralogical characteristics, typical for this type of basalt, will be readily identifiable using the instrumentation available for the upcoming Mars missions.

\subsubsection{IC08, altered phonolite}

The 09IC08 altered "phonolitic-basalt" is from El Teide volcano, Tenerife (N $28^{\circ} 261379$; E $\left.16^{\circ} 594848\right)$. Tenerife is the exposed part of a giant volcanic construct that extends from the floor of the eastern central Atlantic at $-3700 \mathrm{~m}$ to $+3718 \mathrm{~m}$ at the summit of the volcano. The volcano produces different types of magma, especially basalts and phonolites (Ablay and Marti, 2000).

This sample is a massive black rock with a microvesicularity and some vesicles resembling cracks (Fig. 2e). In thin section, the matrix appears to be composed of elongated plagioclases without preferential orientation in a matrix containing euhedral to subeuhedral amphiboles, apatites, spinels and some quartz grains (Fig. $2 \mathrm{f}$ and Table 3). The rock is well crystallised, although discrete preferential orientation of the plagioclases could indicate a 
"paleoflow" lava stage during its formation. This phonolite contains some amphiboles and other hydrous silicates, indicating a water-rich melt.

Due to its characteristics, the sample 09IC08 is a good chemical analogue of weathered Martian basaltic rocks.

\subsubsection{ZA20, silicified basalt}

07ZA20 is a silicified pillow basalt originating from the Kromberg Formation (3.42$3.33 \mathrm{~Gy}$ ) in the Barberton greenstone belt, South Africa (S 26035556, E30 998611$)$. High seawater silica contents and hydrothermal silica enrichment of the Early Archean seawater led to the silicification of the basalts and intervening sediment layers (cf. Hofmann and Bohlar, 2007). In spite of their age, the basalts are well preserved, having been affected only by lower greenschist facies metamorphism.

In hand specimen, the sample is a massive green rock with a fine-grained vesicular texture and a weathered brown crust (Fig. $2 \mathrm{~g}$ ). In thin section, the basalt consists of glass with major plagioclase associated with microlites of amphibole and other accessory minerals, such as spinels and clinochlore (Fig. 2h). Calcite occurs in the vesicles. The basaltic glass has been altered to chlorite and clays. The ubiquitous presence of quartz shows that the bulk sample is highly silicified.

Silicified basalts have not yet been observed on the Martian surface. However, the surface of the pillow basalt is characterized by a vitreous crust similar to those observed by Furnes et al. (2004; 2007), where they described purported fossil traces of microbial activity. The Early Archaean silicified altered pillow basalt 07ZA20 from Barberton could be comparable to Noachian basalts formed in silica-enriched seawater and/or under the influence of silica-dominated hydrothermal activity potentially suitable for the development of primitive microorganisms. 


\subsubsection{CA02 and 10ZA09, fresh and altered komatiites}

Komatiites are olivine and pyroxene cumulates characterized by an acicular "spinifex" texture (Fig. 2i and 2k; Arndt et al., 2003).

The sample 11CA02 is a relatively fresh komatiite from Dundonald, Ontario in Canada (N 48 $\left.655906, \mathrm{E}-80^{\circ} 810322\right)$. Dundonald Beach is situated in the Kidd-Munro formation (2,719-2,710 Gy) of the Abitibi Greenstone Belt. This sample, provided by Nick Arndt (University of Grenoble, France), was collected from the upper part of a five meters, vertically zoned intrusive sill (Arndt et al., 2004). It was sampled about $25 \mathrm{~cm}$ beneath the upper contact. The rock is massive and dark-coloured with a thin brownish alteration layer. The polished surface shows centimetre long acicular pyroxenes and altered dark olivines with a spinifex texture (Fig. 2i). In thin section, the pyroxene crystals are zoned: their augitic core is replaced by pigeonite in periphery. The olivines are altered to hydrothermal amphibole (tremolite-actinote, formed between $\sim 300^{\circ}-350^{\circ} \mathrm{C}$; Fig. $2 \mathrm{j}$ ) that are elongated and often show skeletal overgrowths, and are associated with Ti-spinels and minor sulphides (Ni-Fe).

The sample 10ZA09 originates from the type locality on the Komatii River in the Barberton Greenstone Belt, South Africa (S 26ํ035556, E 30998611). It comes from the Kromberg formation (3.42-3.33 Gy) in the Onverwacht group. As for the silicified basalts from Barberton 07ZA20 (see part 3.1.4), these rocks have been affected by regional lower greenschist metamorphism. The sample is a silicified, komatiitic basalt with a highly altered spinifex texture (Fig. 2k). The structure and the bulk chemical composition are however still preserved. Silicification favoured preservation of the rock although it induced a marked loss of $\mathrm{Ca}, \mathrm{Al}$ and $\mathrm{Mg}$.

In a fresh rough surface, the sample 10ZA09 is textureless, almost glassy in appearance. Thin section study documents significant alteration. Although the sample still 
exhibits the typical olivine spinifex texture, the olivines are totally altered to amphibole and phyllosilicates (Fig. 21). Some talc fibres can be observed. The other major phase of pyroxenes is also altered to talc, micas and phyllosilicates (originally clays, now mica). Some accessory grains of iron oxide, such as hematite, occur together with dolomite.

The komatiite samples 11CA02 and 10ZA09 are particularly relevant because they are primitive Mg-rich basic volcanics, typically abundant in the Archaean period on Earth and possibly on Mars in Noachian terranes (Reyes and Christensen, 1994; Nna-Mvondo and Martinez-Frias, 2007). Moreover, similar textures were observed in artificial Fe-Mg rich Martian like basalts (Bost et al., 2012).

\subsection{Magmatic rocks}

\subsubsection{Sample 09SJ02: Dunite}

Dunite xenoliths occur in the sample 09SJ15 (tephritic basalt from Svalbard, N $\left.79^{\circ} 437583, \mathrm{E} 13^{\circ} 341433\right)$. The dunite is a coarsely crystalline (1-2 mm grain size), green coloured rock (Fig. 2m). The rock consists of olivine and pyroxene (enstatite) associated with spinels (Fig. 2n). Where altered at their edges, the dunite xenoliths are marked by a reduction in grain size.

Sample 09SJ02 could be an analogue of possible Martian deep crustal or mantle rocks exposed at the surface after an impact or an eruption. Typical dunites are observed in the SNC meteorites (e.g. Steele et al., 2007).

\subsection{Sedimentary samples}

\subsubsection{SJ05, hydrothermal carbonates}


09SJ05 corresponds to the brown mamillated carbonates crust coming from a fumarole vent associated with the low vesicular basalt 09SJ15 with dunite xenoliths 09SJ02 from Svalbard (N 79437583, E $13^{\circ} 341433$; Fig. 3a). These zoned carbonates were deposited by hydrothermal exhalation or possibly by aqueous alteration during eruption under an ice cap (Steele et al., 2007; Amundsen et al., 2011).

In thin section (Fig. 3b), the carbonate crusts are zoned parallel to the basalt fragment surfaces indicating composition zoning. The carbonate phase immediately adjacent to the basalt surface is dolomite, followed by ankerite and magnesite representing the outermost layer. Carbonate rosettes, mix of $\mathrm{Ca}, \mathrm{Fe}, \mathrm{Mg}$ carbonates, also occur within vesicles in the basalt. These carbonate deposits have been proposed as analogues of the carbonate rosettes found in the ALH84001 meteorite and in the Comanche Martian outcrop in Gusev Crater (Treiman et al., 2002; Morris et al., 2011).

\subsubsection{CY04, carbonate in altered pillow basalts}

The 11CY04 sample is a hydrothermal carbonate associated with the upper unit of pillow-lavas constituting the top of the Olympus sequence of the Troodos ophiolitic unit, in Cyprus (N 35 04756, E $\left.32^{\circ} 54583\right)$. The sample was obtained from a network of carbonated hydrothermal veins (stockwerk).

The hand specimen (Fig. 3c) is characterized by a clear carbonated microlitic cement enveloping angular clasts (up to $1 \mathrm{~cm}$ ). The carbonate precipitate is banded and highly vesicular (Fig. 3d). The partially altered basaltic clasts are composed of orthoclase, augite, phyllosilicates (montmorillonite group) and minor anatase (determined by Raman spectrometry). Some rare euhedral calcite-dolomite crystals are also visible.

The carbonate alteration product of basalt $11 \mathrm{CY} 04$ can be considered as a good analogue of the Comanche Martian outcrop (Morris et al., 2011). 


\subsubsection{ZA01, carbonaceous hydrothermal chert}

99ZA01 is a carbonaceous hydrothermal chert vein coming from the Buck Reef Chert (3.42 Gy), Kromberg Formation of the Onverwacht Group, Barberton Greenstone Belt, South Africa $\left(\mathrm{N}-26^{\circ} 555, \mathrm{E} 23^{\circ} 49681\right)$. It was a feeder vein that follows a syn-sedimentary growth fault cutting across the underlying volcanics and into the sedimentary layers deposited in a large basinal structure.

The sample is a massive black chert with white quartz veinlets (Fig. 3e). In thin section the chert has a fine-scale granular texture consisting of small carbonaceous particles in a micro-crystalline quartz matrix (Fig. 3f). Part of the sample consists of brecciated material having the same compositional and textural characters as the bulk sample. Small pyrite grains occur as accessory minerals.

Sample 99ZA01 could be an analogue of hydrothermal silica deposits on Mars. Silicarich hydrothermal fluids had an important influence on the early Earth, evidence of which is documented in these sediments (Hofmann and Bohlar, 2007) and there is some evidence of hydrothermal silica on Mars (e.g. Ehlmann et al., 2009; Squyres et al., 2008; Ruff et al., 2011).

\subsubsection{ZA05, hydrothermal chert vein}

The sample 99ZA05 consists of stratified silicified sediments from the Buck Reef Chert (3.42 Gy), Kromberg Formation of the Onverwacht Group, Barberton Greenstone Belt, South Africa (N $\left.-26^{\circ} 555, \mathrm{E} 23^{\circ} 49681\right)$, that have been infiltrated parallel to the sediment layering by a hydrothermal chert vein. The infiltration occurred possibly during diagenetic or post diagenetic lithification of the sediments by silicification (a rapid process, cf. Hofmann and Bohlar, 2007). 
The hand specimen is a laminated black and white chert (Fig. 3g). The original sedimentary layering and sedimentary textures can still be seen, as well as intrusive layers of bedding parallel hydrothermal chert: laminae thicknesses range from $2 \mathrm{~mm}$ to $2 \mathrm{~cm}$ (Fig. $3 \mathrm{~g}$ ). The laminated texture and sedimentologic structures are highlighted on the weathered surface of the sample whereas the unweathered surface is uniformly black and the structures are difficult to see. In thin section, the hydrothermal chert layer consists of uniform microcrystalline quartz (Fig. 3h). Intrusion of the hydrothermal layer into the sediments caused brecciation of the upper contact. Rare carbon-containing inclusions occur within the hydrothermal chert. The host rock consists of layers of volcanic clasts $(1-5 \mathrm{~mm})$ that include a horizon of long slivers of silicified, finely laminated carbonaceous clasts (fig.3-h). These may represent fragments of silicified microbial mats (cf. Tice and Lowe, 2004; 2006; Tice, 2009). The whole sediment was lithified prior to intrusion of the hydrothermal vein.

Sample 99ZA05, as with sample 99ZA01, can be considered as an analogue of a hydrothermal silica vein on Mars.

\subsubsection{AU01, banded iron formation (BIF)}

The 06AU01 BIF sample originates from the Coppin Gap Greenstone Belt, Pilbara Craton in Australia (S 20892717, E 120³49680). Stratigraphically, it belongs to the Panorama Formation of Warrawoona Group, as does the silicified volcanic sand (sample 00AU05) from the nearby-located Kitty’s Gap Chert (see below).

This rock is a fine-grained, red and white laminated chert. The laminae range from 0.5 to $2 \mathrm{~cm}$ in thickness (Fig.3i). Fe-stained fractures and fractured layering can be seen on hand specimen. The weathered surface is composed of fine-grained goethite-hematite and other undefined nanometric iron oxides. In thin section, the white layers consist of microcrystalline quartz (Fig.3j). They are extremely finely layered, the laminae having thicknesses of 10- 
$100 \mu \mathrm{m}$. The layers are delicately wavy or occur in packets $\sim 1 \mathrm{~mm}$ thick of conformable laminae. Soft sediment deformation structures occur. The red layers are rich in fine-grained iron oxides. Large lozenge-shaped crystals of pseudomorphosed dolomite (now Fe oxide) are found at the contact between the Fe-poor and Fe-rich layers exhibiting ghost layering similar to that in the Fe-poor layers. The whole sediment is criss-crossed by fine Fe-rich or Si-rich fractures. Stylolites also occur.

Terrestrial BIFs are aqueously formed sediments consisting of alternating $\mathrm{Si}$ - and $\mathrm{Fe}-$ rich layers that were common in the Archaean and Proterozoic epochs. They were deposited in basin settings through the oxidation of reduced Fe introduced into the seawater mostly by hydrothermal fluids. The exact origin of these sediments, i.e. the mechanisms for oxidizing the Fe (possibly microbial) and for the layering (seasonal/microbial?) is still highly debated (Posth et al., 2010). BIFs have not yet been discovered on Mars, but their eventual presence can be hypothesised on the basis of the high Fe-content of Martian rocks (15 to $18 \mathrm{wt} \%$ on average; e.g. McSween et al., 2009) and the detection of hydrothermal silica-rich deposits on Mars (e.g. Squyres et al., 2008; Ruff et al., 2011).

\subsubsection{AU04, hydrothermal chert from Kitty's Gap}

This sample belongs to the Panorama Formation of the Warrawoona Group, Pilbara, Australia (S $20^{\circ} 5345$, E $120^{\circ} 044$ ). The chert vein crosscuts the basal sediments of the Kitty's Gap Chert (3.446 Gy). Intraformational brecciation of the lowermost layers of the sedimentary horizon indicates that the hydrothermal activity was coeval with sediment deposition.

This sample consists of a $2 \mathrm{~cm}$-thick black vein of hydrothermal chert that crosscuts volcanoclastic sediments consisting largely of pumice fragments, $5 \mathrm{~mm}$ in size (Fig. 3k). In thin section, the microcrystalline quartz vein is basically featureless except for some rare 
carbon and anatase inclusions (Fig.31). Although silicified, the vesiculated pumice fragments are well preserved. Some $0.5 \mathrm{~mm}$-long euhedral crystals with a lozenge shape and coated with anatase might be ghost zircons.

Sample 00AU04 is an analogue of hydrothermal silica deposits on Mars (cf. samples 99ZA01 and 99ZA05). This sample is also associated with silicified volcanic sediments that host traces of life (see sample 00AU05 below).

\subsubsection{AU05, Chert from Kitty's Gap}

The sample 00AU05 is a silicified volcanic sand/silt from the 3.446 Gy-old Kitty's Gap Chert of the Panorama Formation in the Warrawoona Group of the Pilbara Craton, Australia (de Vries et al., 2004). Like the BIF sample 06AU01 described above, it is also located in the Coppin Gap Greenstone Belt (S 205345, E $120^{\circ} 044$ ), just to the west and stratigraphically below the sample 06AU01 (described above). The outcrop consists of laminated black and white chert representing silicified volcanic sands and silts deposited in a mud flat/tidal channel environment (de Vries et al., 2006). The sedimentary structures, including ripple, channel and flaser bedding, are clearly visible. The sediment contains cryptic morphological and carbonaceous traces of life (Westall et al., 2006b; 2011a; Orberger et al., 2006).

The sample is characterised by submillimetre- to millimetre-thick black and white laminae (Fig. $3 \mathrm{~m}$ ). The laminae are more visible on the weathered rock surface than on the unweathered one. Sedimentary structures include ripple bedding (bimodal), flaser linsen bedding and channel bedding. Layers of small pumice fragments $(<0.5 \mathrm{~cm}$ diameter $)$ also occur. Thin section analysis shows that the differences in colour between the black and white layers are related to grain size, the darker layers being finer-grained than the white ones (Fig. $3 n)$. The sediment consists of volcanic clasts that have been silicified. The sediment matrix 
consists of silica and three types of ghost clasts now consisting of hydromuscovite and Tioxide spherules. A chert vein consisting of mainly featureless microcrystalline quartz crosscuts the silicified sediment. Similar chert veins also formed as bedding parallel intrusion sills.

Sample 00AU05 is an analogue of layered volcanic sediments on Mars. It hosts traces of primitive life in the form of carbonaceous microfossils that could be used as reference to hypothetical traces of primitive life on Mars (Westall et al., 2011a).

\subsubsection{AR01, artificial Fe-nontronite}

The sample 10AR01 is a pure Fe-nontronite synthesised at $150^{\circ} \mathrm{C}$ in the IC2MP laboratory, Poitiers, France, by the team of S. Petit and A. Meunier. Cristallographic characterization was performed by Decarreau et al. (2008).

The nontronite is a mineral analogue to the "residue" of weathered basalts on Mars. This laboratory-synthesised nontronite was chosen as an analogue of phyllosilicates formed by basalt alteration in neutral conditions on Mars (Bibring et al., 2006; Meunier et al., 2010). Carbonaceous material is often associated with phyllosilicates, thus increasing their interest in terms of the search for either prebiotic or biotic carbon molecules.

\section{Discussion}

Fifteen initial samples were selected for their analogy with Mars and have been fully characterized by various techniques (except for detailed analysis of the organic compounds which is planned in the immediate future). These samples and their associated descriptions are accessible via the website www.isar.cnrs-orleans.fr for testing and calibrating space instruments [Note that the collection now contains more than 50 specimens]. Our investigations show that, depending on the nature of the sample, its preparation, and the 
analytical technique used, an interpretation based on one analysis method only often yields mediocre results. It is clear that the best results accrue from the complementary use of several techniques. Furthermore, obvious performance differences exist between laboratory instruments, such as those used to characterize the ISAR rocks, and the miniaturised, robotic instruments that can be embarked on Mars missions. This means that interpretations made on the basis of in-situ instrument results may be more problematic in specific situations. A qualitative evaluation of the reliability of identification of structure, texture, mineralogy or composition by the individual instruments is given in Tables 4 and 5. This comparison demonstrates that, even using laboratory equipment, some very common rocks and minerals on Mars can be difficult to identify, in particular if the instruments have not been previously calibrated. This finding underpins the utility of the ISAR samples for characterising the entire suite of instrumentation on a mission. Tables 4 and 5 also demonstrate the necessity to use several techniques in order to facilitate rock identification. In certain circumstances, when associated with other measurements, even the absence of signal from an instrument can aid interpretation. For example in near IR spectroscopy quartz is invisible, but readily detectable with Raman spectroscopy. Another example of useful combination of techniques is Raman spectral mapping enhanced by cathodoluminescence imagery (Thomas et al., 2009), which can provide information on mineralogy, texture, and structure.

Our results also demonstrate the inherent limitations of using only powder preparations when seeking to make geologically relevant interpretations. Textural and structural information based on outcrop macroscopic and microscopic observations, in association with mineralogy and elemental chemistry, are essential for determining rock type and history and, hence, the relevance of a certain rock type for habitability and its potential for preserving signatures of life (Foucher et al., 2013). At least the crucial visual information must be obtained prior to crushing, and if possible the co-registered spectral data too. On 
Curiosity, the CHEMCAM instrument combines remote LIBS and high-resolution camera information for surface targets. However, also on Curiosity, the CHEMIN XRD/XRF instrument and, on the ExoMars rover, the VIS-IR and Raman spectrometers will provide data obtained from a powder. On Mars, where the resolution of the rover instruments is lower than that of laboratory instruments, we estimate that only about $50 \%$ of the rock-forming minerals characterized in our study could be reliably identified. The initial determination of rock type on Mars will depend heavily on information obtained from the colour panoramic camera together with the colour microscope (acting as a handlens). The use of a rock abrasion tool to obtain a weathering free, smooth surface for further observation and analysis is very important for surface rock identification. Clearly this cannot be achieved in the case of small samples obtained with a drill

As noted above, the experimental settings of instrumentation in the laboratory is not the same as those of the flight instruments. For example, the ExoMars' IR instrument, MicrOmega, will operate in reflection mode while we made analyses in classical transmission mode for which there are larger spectral databases. These variations in instrumentation settings and techniques, which could lead to differences in the results, making it all the more important to test flight instrumentation with the same suite of well characterized Mars analogue samples.

\section{Conclusions}

We have created a first collection of Mars-analogue rocks and minerals for testing and calibrating space instrumentation for in-situ missions to Mars, such as MSL and ExoMars. These materials include a variety of basalts, the most common rock type on Mars, volcanic and chemical sediments (carbonates, BIF, cherts), and the phyllosilicate nontronite, that are relevant in terms of structure, texture, mineralogical and geochemical composition. There are 
certain limitations in using terrestrial materials as analogues of Martian materials. These are related to some major geochemical differences in the compositions of, especially, Fecontaining rocks on the two planets (for example, Martian basalts contain much more Fe and $\mathrm{Mg}$ than terrestrial basalts on Earth). Nevertheless, the terrestrial rocks we have chosen correspond as closely as possible to Martian materials.

Laboratory instrumentation was used to fully characterise the samples. It was frequently necessary to use complementary information obtained from a variety of techniques to identify a rock or a mineral. Analyses made on rock surfaces (cleaned and/or polished) were more useful for rock identification than those made on crushed rock, where texture, mineral context, and even the relative proportions of minerals are blurred or altogether obliterated.

Instrument testing and calibration with the same suite of standards is necessary for good identification of rocks and minerals on Mars. The geological context is crucial for understanding the conditions of habitability and for evaluating the potential of the rocks for preserving traces of life. These samples and their full descriptions are deposited in the International Space Analogue Rockstore, in Orléans, accessible via the website www.isar.cnrs-orleans.fr. The materials in the ISAR, including these samples and others minerals, can be loaned out or given (in the case of destructive analyses) for instrument testing directly from the website. We hope that the ISAR collection of rocks and minerals and its associated online database will help during the testing and calibration phase before and during missions to Mars. In the near future, the expansion of the scientific community involved in the ISAR project will help to increase the number of samples and data in the collection. The development of collaborations between the different teams will also improve the scientific return of surface missions dedicated to geology and astrobiology. 


\section{Acknowledgments}

We acknowledge the Centre National d'Etudes Spatiales (CNES) and the Region Centre for funding, the NASA-AMASE Program (A. Steele and H. Amundsen) for the opportunity to sample on Svarlbard, N. Arndt and S. Roto for providing some key samples for the Mars analogue Rockstore, and the European Space Agency (ESA) for supporting us. We acknowledge M. Viso, S. Janiec, J.-G. Badin, I. DiCarlo, O. Rouer, P. Penhoud, B. Cavalazzi, G. Lopez-Reyes, F. Rull, and the reviewers for analysis and comments.

\section{Bibliography}

Ablay, G.J., and Marti, J., 2000. Stratigraphy, Structure, and Volcanic Evolution of the Pico Teide-Pico Viejo Formation, Tenerife, Canary Islands. J. Volcanol. Geoth. Res. 103, 175208.

Amundsen, H.E.F., Benning, L., Blake, D.F., et al., 2011. Cryogenic origin for Mars analogue carbonates in the Bockfjord volcanic complex, Svalbard (Norway). Lunar Planet. Sci. XXXXII, 2223 (abstract).

Anderson, R.C., Dohm, J.M, Golombek, M.P., et al., 2001. Primary centers and secondary concentrations of tectonic activity through time in the western hemisphere of Mars. J. Geophys. Res. 106, 20.523-20.585.

Arndt, N.T., 2003. Komatiites, kimberlites, and boninites, J. Geophys. Res. 108, 2293.

Arndt, N.T., Lesher, C.M., Houlé, M.G., Lewin, E., Lacaze, Y., 2004. Intrusion and Crystallization of a Spinifex Textured Komatiite Sill in Dundonald Township, Ontario. J. Petrol. 45, 2555-2571.

Bandfield, J.L., Hamilton, V.E., Christensen, P.R., McSween, H.Y., 2004. Identification of quartzofeldspathic materials on Mars. J. Geophys. Res. 109, E10009. 
Bibring, J.-P., Langevin, Y., Mustard, J.F., et al., 2006. Global Mineralogical and Aqueous Mars History Derived from OMEGA/Mars Express Data. Science 312, 400-404.

Borg, L.E., Connelly, J.N., Nyquist, L.E, Chih, C.-Y., Weismann, H., Reese, Y., 1999. The age of carbonates in Martian meteorite ALH84001. Science 186, 90-94.

Bost, N., Westall, F., Gaillard, F., Ramboz, C., Foucher, F., 2012. Synthesis of a spinifextextured Basalt as an analog to Gusev crater basalts, Mars. Meteorit. Planet. Sci. 45, 820831.

Boynton, W.V., Ming, D.W., Kounaves, S.P. et al., 2009. Evidence for Calcium Carbonate at the Mars Phoenix Landing Site. Science 325, 61-64.

Breuer, D., Labrosse, S., Spohn, T., 2010. Thermal evolution and magnetic field generation in terrestrial planets and satellites. Space Sci. Rev. 152, 449-500.

Bullock, M.A., Stoker, C.R., McKay, C.P., Zent, A.P., 1994. A coupled Soil-Atmosphere Model of $\mathrm{H}_{2} \mathrm{O}_{2}$ on Mars. Icarus 107, 142-154.

Carr, M.H., Head, J.W., 2009. Geologic history of Mars. Earth. Planet. Sc. Lett. 294, 185-203.

Cavalazzi, B., Westall, F., Cady, S.L., Barbieri, R., Foucher, F., 2011. Potential fossil endoliths in vesicular pillow basalt, Coral Patch Seamount, eastern North Atlantic Ocean. Astrobiology 11, 619-632.

Christensen P.R., McSween, H.Y., Bandfield, J.L., et al., 2005. Evidence for magmatic evolution and diversity on Mars from infrared observations. Nature 436, 504-509.

Coltelli, M., Del Carlo, P., Pompilio, M., Vezzoli, L., 2005. Explosive eruption of a picrite: The 3930 BP subplinian eruption of Etna volcano (Italy), Geophys. Res. Lett. 32, L23307. Decarreau, A., Petit, S., Martin, F., Farges, F., Vieillard, P., Joussein, E., 2008. Hydrothermal synthesis, between 75 and $150^{\circ} \mathrm{C}$, of high-charge, ferric nontronites. Clay Clay Miner. 56, $322-327$. 
de Vries, S.T., 2004. Early Archaean sedimentary basins: Depositional environment and hydrothermal systems. Geol. Utraiectina 244, 1-160.

de Vries, S.T., Nijman, W., Wijbrans, J.R., Nelson, D.R., 2006. Stratigraphic continuity and early deformation of the central part of the Coppin Gap Greenstone Belt, Pilbara, Western Australia. Precambrian Res. 147, 1-27.

Ehlmann, B.L., Mustard, J.F., Murchie, S.L., et al., 2008. Orbital Identification of Carbonates-Bearing Rocks on Mars. Science 322, 1828-1832.

Ehlmann, B.L., Mustard, J.F., Swayze, G.A. et al., 2009. Identification of hydrated silicate minerals on Mars using MRO-CRISM: Geologic context near Nili Fossae and implications for aquaeous alteration. J. Geophys. Res. 114, E00D08.

Ehlmann, B.L., Mustard, J.F., Murchie, S.L., 2010. Geologic setting of serpentine deposits on Mars. Geophys. Res. Lett. 37, L06201.

Foucher, F., Lopez-Reyes, G., Bost, N., Rull-Perez, F., Rüßmann, P., Westall, F., 2013. Effect of grain size distribution on Raman analyses and the consequences for in situ planetary missions. J. Raman Spectrosc., in press.

Furnes, H., Banerjee, N.R., Muehlenbachs, K., Staudigel, H., de Wit, M., 2004. Early Life Recorded in Archean Pillow Lavas. Science 304, 578-581.

Furnes, H., Banerjee, N.R., Staudigel, H., et al., 2007. Comparing petrographic signatures of bioalteration in recent to Mesoarchean pillow lavas: tracing subsurface life in oceanic igneous rocks. Precambrian Res. 158, 156-176.

Grotzinger, J.P., Blake, D.F., Crisp, J., et al., 2013. Mars Science Laboratory: First 100 sols of Geologic and Geochemical Exploration fro Bradbury Landing to Glenelg. $44^{\text {th }}$ Lunar and Planetary Science Conference. Abstract 1259.

Gellert, R., Rieder, R., Anderson, R.C., et al., 2004. Chemistry of Rocks and Soils in Gusev Crater from the Alpha Particle X-ray Spectrometer. Science 305, 829-832. 
Gellert R., Rieder, R., Brückner, J., et al., 2006. Alpha Particle X-Ray Spectrometer (APXS): Results from Gusev crater and calibration report. J. Geophys. Res. 111, E02S05.

Glotch, T.D., Bandfield, J. L., Christensen, P. R., et al., 2006. Mineralogy of the light-toned outcrop at Meridiani Planum as seen by the Miniature Thermal Emission Spectrometer and implications for its formation, J. Geophys. Res. 111, E12S03.

Hofmann, A., Bolhar, R., 2007. The origin of carbonaceous cherts in the Barberton greenstone belt and their significance for the study of early life in mid-Archaean rocks. Astrobiology 7, 355-388.

Hoehler, T., Westall, F., 2010. MEPAG goals for Mars Exploration: update of Goal 1: determine if life ever arose on Mars. Mars Exploration program Advisory Group meeting, Monrovie, CA-USA, 17-18 mars 2010.

Holt, J.W., Fishbaugh, K. E., Byrne, S., et al., 2010. The construction of chasma boreale on Mars. Nature 465, 446-449.

Izawa, M.R., Banerjee, M., Flemming, R.L., Bridge, N.J., Schultz, C., 2010. Basaltic glass as a habitat for microbial life: Implications for astrobiology and planetary exploration. Planet. Space Sci. 58, 583-591.

Klingelhöefer, G., Morris, R.V., Bernhardt, B., et al., 2003. Athena MIMOS II Mössbauer spectrometer investigation. J. Geophys. Res. 108, 8067.

Kminek, G., Bada, J.L., 2006. the effect of ionizing radiation on the preservation of amino acids on Mars. Earth. Planet. Sc. Lett. 245, 1-5.

Komiya, T., Maruyama, S., Masuda, T., Nohda, S., Hayashi, M., Okamoto, K., 1999. Plate Tectonics at 3.8-3.7 Ga: Field Evidence from the Isua Accretionary Complex, Southern West Greenland. J. Geol. 107, 515-554.

LeBas, M., 2000. IUGS Reclassification of the High-Mg and Picritic Volcanic Rocks. J. Petrol. 41, 1467-1470. 
McLennan, S.M., Bell III, J.F., Calvin, W.M., et al., 2005. Provenance and diagenesis of the evaporite-bearing Burns formation, Meridiani Planum, Mars. Earth. Planet. Sc. Lett 240, 95-121.

McSween, H.Y., Arvidson, R.E., Bell III, J.F., et al., 2004. Basaltic Rocks Analyzed by the Spirit Rover in Gusev Crater. Science 305, 842-845.

McSween, H.Y., Taylor, G.J., Wyatt, M.-B., 2009. Elemental Composition of the Martian Crust. Science 324, 736-739.

Meunier, A., Petit, S., Cockell, C.S., El Albani, A., Beaufort, D., 2010. The Fe-Rich Clay Microsystems in Basalt-Komatiite Lavas: Importance of Fe-Smectites for Pre-Biotic Molecules Catalysis During the Adean Eon. Origins Life Evol. B. 40, 253-272.

Michalski, J.R., Kraft, M.D., Sharp, T.G., Williams, L.B., Christensen P.R., 2005. Mineralogical constraints on the high-silica Martian surface component observed by TES. Icarus $174,161-177$.

Michalski, J.R., Niles, P.B., 2010. Deep crustal carbonate rocks exposed by meteor impact on Mars. Nature Geoscience 3, 751-755.

Milliken, R.E., Swayze, G.A., Arvidson, R.E., et al., 2008. Opaline silica in young deposits on Mars. Geology 36, 847-850.

Morris, R.V., Klingelhöfer, G., Schröder, C., et al., 2010. Identification of Carbonate-Rich Outcrops on Mars by the Spirit Rover, Science 329, 421-424.

Nna-Mvondo, D., Martinez-Frias, J., 2007. Review komatiites: from Earth's geological settings to planetary and astrobiological contexts. Earth Moon Planets 100, 157-179.

Orberger, B., Rouchon, V., Westall, F., et al., 2006. Microfacies and origin of some Archean cherts (Pilbara, Australia), in: Reimold, W. U., and Gibson, R. L. (Eds.) Processes on the Early Earth. Geological Society of America Special Paper 405, Geological Society of America, pp.133-156. 
Orgel, L.E., 1998. The origin of life - a review of facts and speculations. Trends Biochem. Sci. 23, 491-495.

Papike, J.J., Karner, J.M., Shearer, C.K., Burger, P.V., 2009. Silicate mineralogy of Martian meteorites. Geochim. Cosmochim. Acta73, 7443-7485.

Posth, N., Konhauser, K., Keppler, A., 2010. Banded iron formations, in: Reitner, J., and Thiel, V. (Eds.), Encyclopedia of Geobiology, Springer, Berlin, pp. 92-102.

Poulet, F., Bibring, J.-P., Mustard, J.F., et al., 2005. Phyllosilicates on Mars and implications for early Martian climate. Nature 438, 623-627.

Pullan, D., 2008. Analogue Studies for In Situ Surface Planetary Exploration. PhD Thesis, University of Leicester.

Reyes, D.P., Christensen, P.R., 1994. Evidence of Komatiite-type lavas on Mars from Phobos ISM data and other observations. Geophys. Res. Lett. 21, 887-890.

Rieder, R., Gellert, R., Anderson, R.C., et al., 2009. Chemistry of Rocks and Soils at Meridiani Planum from the Alpha Particle X-ray Spectrometer. Science 306, 1746-1749.

Ruff, S. W., Farmer, J.D., Calvin, W.M., et al., 2011. Characteristics, distribution, origin, and significance of opaline silica observed by the Spirit rover in Gusev crater, Mars. J. Geophys. Res. 116, E00F23.

Rull-Pérez, F., Martinez-Frias, J., 2006. Raman Spectroscopy goes to Mars, Spectroscopy Europe 18, 18-21.

Skjelkvåle, B., Amundsen, H.E.F., O’Reilly, S. Y., Griffin, W. L., Gjelsvik, T., 1989. A primitive alakali basaltic stratovolcano and associated eruptive centres, northwestern spitsbergen: Volcanology and tectonic significance, J. Volcanol. Geoth. Res. 37, 1-19.

Smith, M.R., Bandfield J.L., 2012. Geology of quartz and hydrated silica-bearing deposits near Antoniadi Crater, Mars. J. Geophys. Res. 117, E06007, 
Southam, G., Rothschild, L. J., Westall, F., 2007. The Geology and Habitability of Terrestrial Planets: Fundamental Requirements for Life. Space Sci. Rev. 129, 7-34

Steele, A., Fries, M.D., Amundsen, H.E.F., et al., 2007. Comprehensive imaging and Raman spectroscopy of carbonates globules from Martian meteorite ALH 84001 and a terrestrial analogue from Svalbard. Meteorit. Planet. Sci. 42, 1549-1566.

Squyres, S.W., Arvidson, R.E., Ruff, S., et al., 2008. Detection of Silica-Rich Deposits on Mars. Science 320, 1063-1067.

Stoker, C.R., and Bullock, M.A., 1997. Organic Degradation under simulated Martian Conditions. J. Geophys. Res. 102, 10881-10888.

Stolper, E.M., Baker, M.B., Fisk, M., et al., 2013. The Petrochemistry of Jake_M: A Martian Mugearite. $44^{\text {th }}$ Lunar and Planetology Science Conference, Abstract 1685.

Taylor, G.J., McLennan, S.M., McSween, H.Y., Wyatt, M.B., Lentz, R.C.F., 2008. Implications of observed primary lithologies, in: Bell, J. F., (Eds.), The Martian Surface: composition, Mineralogy, and Physical Properties, Cambridge University Press, Cambridge, pp. 501-518,

Thomas, R., Barbin, V., Ramboz, C., et al., 2009. Cathodoluminescence instrumentation for analysis of Martian sediments, in: Pagel, M., Barbin, V., Blanc, P., and Ohnenstetter, D. (Eds.), Cathodoluminescence and its Application in the Planetary Science, Springer Verlag, Berlin Heidelberg New York, pp. 111-126.

Tice, M., Lowe, D.R., 2004. Photosynthetic microbial mats in the 3416-Mys-old ocean. Nature 431, 549-552.

Tice, M., Lowe, D.R., 2006. The origin of carbonaceous matter in pre-3.0 Ga greenstone terrains: A review and new evidence from the 3.42 Ga Buck Reef Chert. Earth-Sci. Rev. 76, 259-300. 
Tice, M., 2009. Environmental controls on photosynthetic microbial mat distribution and morphogenesis on a 3.42 Ga clastic- starved platform. Astrobiology 9, 989-1000.

Tosca N.J., McLennan, S.M., Lindsley, D.H., Schoonen, M.A.A., 2004. Acid-sulfate weathering of synthetic Martian basalt: The acid fog model revisited. J. Geophys. Res. 109, E05003.

Treiman, A.H., Amundsen, H.E.F., Blake, D.F., Bunch, T., 2002. Hydrothermal origin for carbonate globules in Martina meteorite ALH84001: terrestrial analogue from Spitsbergen (Norway). Earth Planet. Sc. Lett. 204, 323-332.

Viles, H., Ehlmann, B., Wilson, C. F., Cebula, T., Page, M., Bourke, M., 2010. Simulating weathering of basalt on Mars and Earth by thermal cycling. Geophys. Res. Lett. 37, L18201.

Wadhwa, M., Borg, L.E., 2006. Trace element and 142 Nd systematics in the nakhlite MIL03346 and the orthopyroxenite ALH84001: Implications for the Martian mantle. Lunar Planet. Sci. XXXVII, 2045 (abstract).

Wanke, H., Brückner, J., Dreibus, G., Rieder, R., Ryabchikov, I., 2001. chemical composition of rocks and soils at the pathfinder site. Space Sci. Rev. 96, 317-330.

Westall, F., 2005. Early life on Earth and Analogies to Mars, in: Tokano, T. (Ed.), Water on Mars and Life, Adv. Astrobiol. Biogephys, Springer, Berlin Heidelberg, doi $10.1007 / \mathrm{b} 12040$.

Westall, F., de Vries, S.T., Nijman, W., et al., 2006a. The 3.466 Ga Kitty’s Gap Chert, an Early Archaean microbial ecosystem, in: Reimold, W.U., and Gibson, R. (Eds.), Processes on the Early Earth, Geol. Soc. Amer. Spec Pub., 405, pp. 105-131.

Westall, F., de Ronde, C.E.J., Southam, G., et al., 2006b. Implications of a 3.472-3.333 Gaold subaerial microbial mat from the Barberton greenstone belt, South Africa for the UV 
environmental conditions on the early Earth. Phil. Trans. Roy. Soc. Lond. Series B. 361, $1857-1875$.

Westall, F., 2008. Morphological Biosignatures in Early Terrestrial and Extraterrestrial Materials. Space Sci. Rev., 135, pp. 95-114.

Westall, F., Foucher, F., Cavalazzi, B., et al., 2011a. Volcaniclastic habitats for early life on Earth and Mars: A case study from 3.5 Ga-old rocks from the Pilbara Australia. Planet. Space Sci. 59, 1093-1106.

Westall, F., Cavalazzi, B., Lemelle, L., et al., 2011b. Implications of in situ calcification for photosynthesis in a $\sim 3.3$ Ga-old microbial biofilm from the Barberton greenstone belt, South Africa. Earth Planet. Sc. Lett. 310, pp. 468-479.

Wyatt, M.B., McSween, H.Y., 2002. Spectral evidence for weathered basalt as an alternative to andesite in the northern lowlands of Mars. Nature 417, 263-266. 


\section{Figures captions}

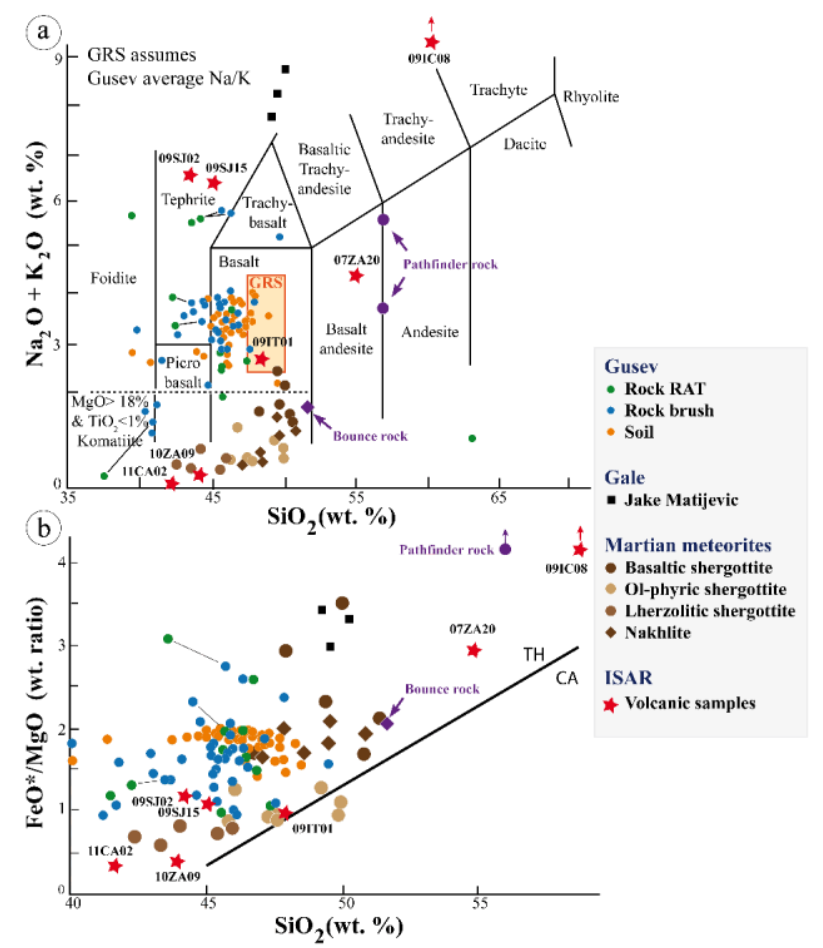

Figure 1- a. Composition of volcanics and soils from the Gusev crater plotted in a total alkalisilica (TAS) diagram used for classification of volcanic rocks (modified after McSween et al., 2009 and Le Bas et al,. 2000). b. FeO*/MgO-silica diagram used for distinguishing dry tholeiitic (TH) and wet calc-alacali (CA) rocks (modified after McSween et al., 2009). Jake Matijevic data are from Stolper et al., 2013. Data points for the same rocks analysed from RAT-brushed and RAT-ground surfaces are connected by tie-lines. The TES measurements are not plotted in the diagram. 


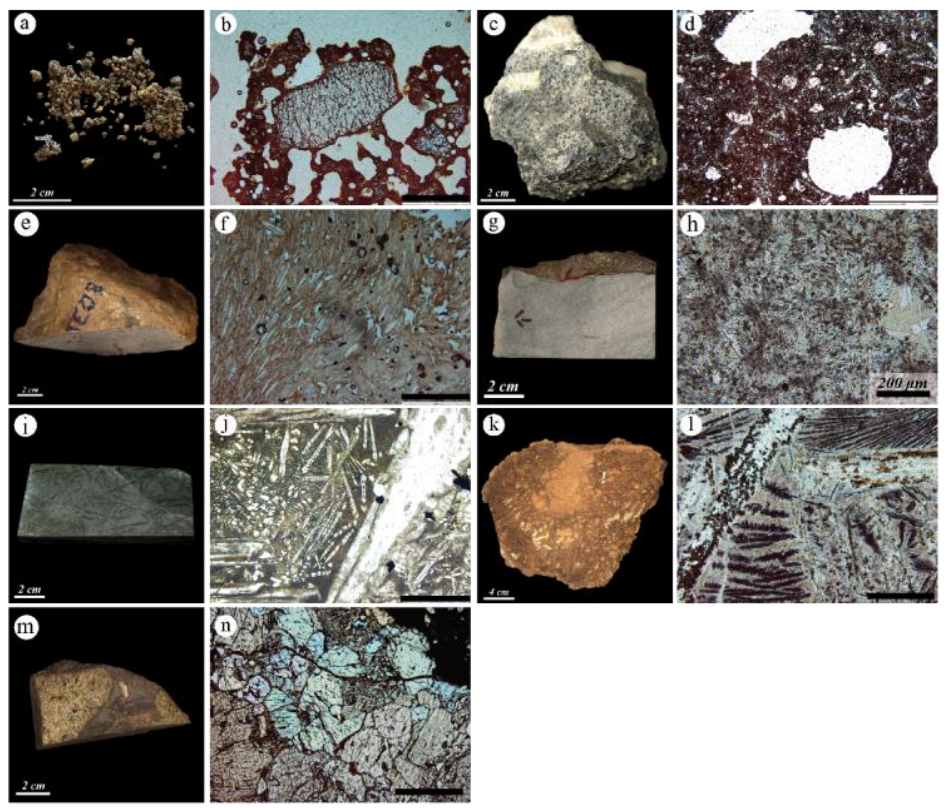

Figure 2- (a, c, e, g, i, k, m) macroscopic views (scale bar is $2 \mathrm{~cm}$ unless specified) and (b, d, $\mathrm{f}, \mathrm{h}, \mathrm{j}, \mathrm{l}, \mathrm{n}$ ) transmitted light microphotographs of thin sections (scale bar is $1 \mathrm{~mm}$ unless specified) of the volcanic and igneous Mars analogue samples. a, b- primitive basalt 09IT01; c, d- picritic basalt 09SJ15; e, f- altered phonolite 09IC08; g, h- altered silicified basalt 07ZA20; i, j- komatiite 11CA02; k, 1- altered komatiite10ZA09 and m, n- xenoliths dunite 09SJ02. 

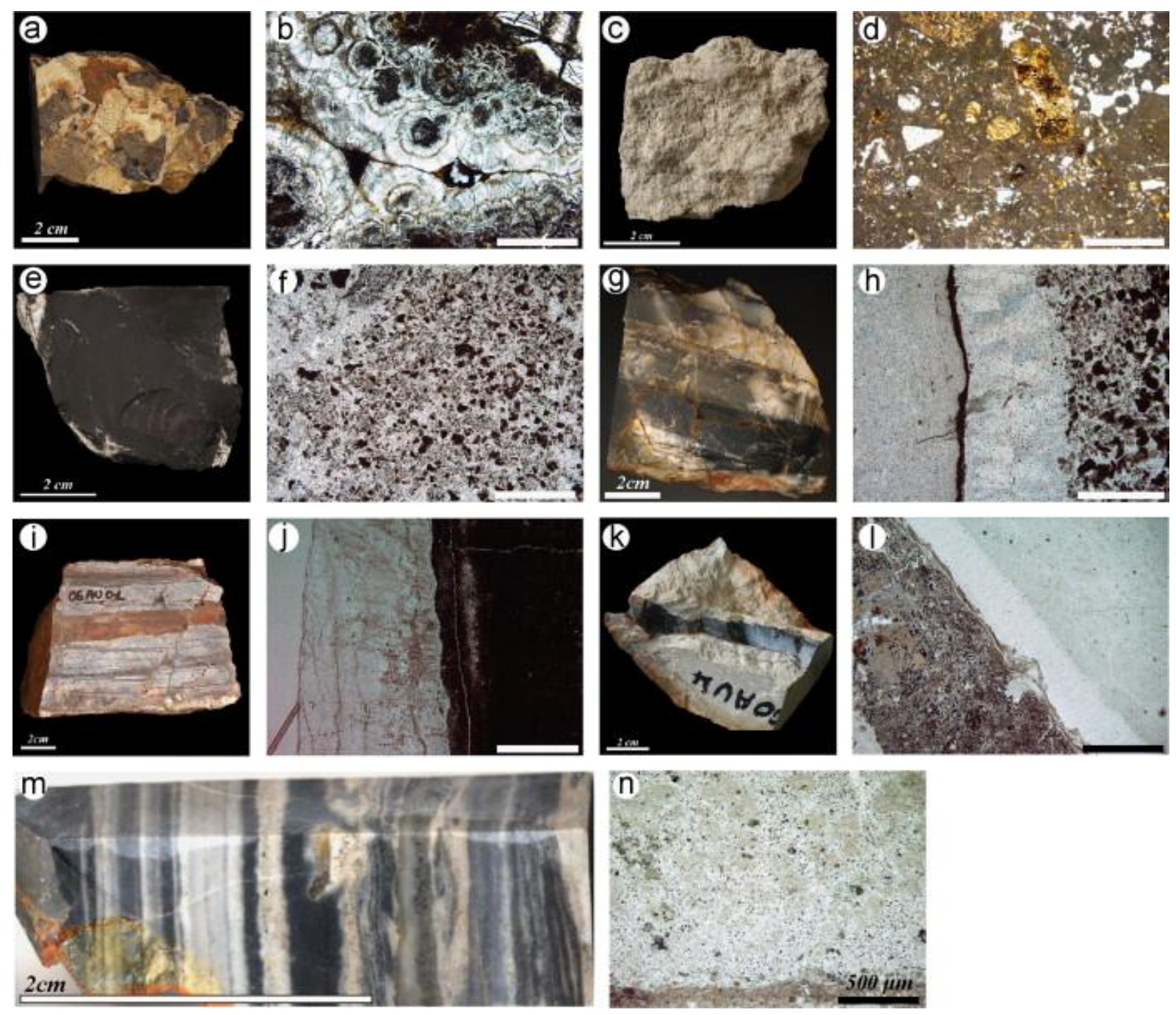

Figure 3 - (a, c, e, g, i, k, m) macroscopic views (scale bar is $2 \mathrm{~cm}$ unless specified) and (b, d, $\mathrm{f}, \mathrm{h}, \mathrm{j}, \mathrm{l}, \mathrm{n}$ ) transmitted light microphotographs of thin sections (scale bar is $1 \mathrm{~mm}$ unless specified) of the sedimentary and hydrothermal Martian analogue samples. a, b- carbonates 09SJ05; c, d- hydrothermal carbonates 11CY04; e, f- carbonaceous hydrothermal chert 99ZA01; g, h- hydrothermal chert 99ZA05; i, j- BIF 06AU01; k, 1- hydrothermal chert 00AU04 and m, n- silicified altered volcanoclastic sediments 00AU04. 
Table 1. Comparison of the MSL and ExoMars payloads and the instrument suites used for laboratory characterisation of the analogue samples

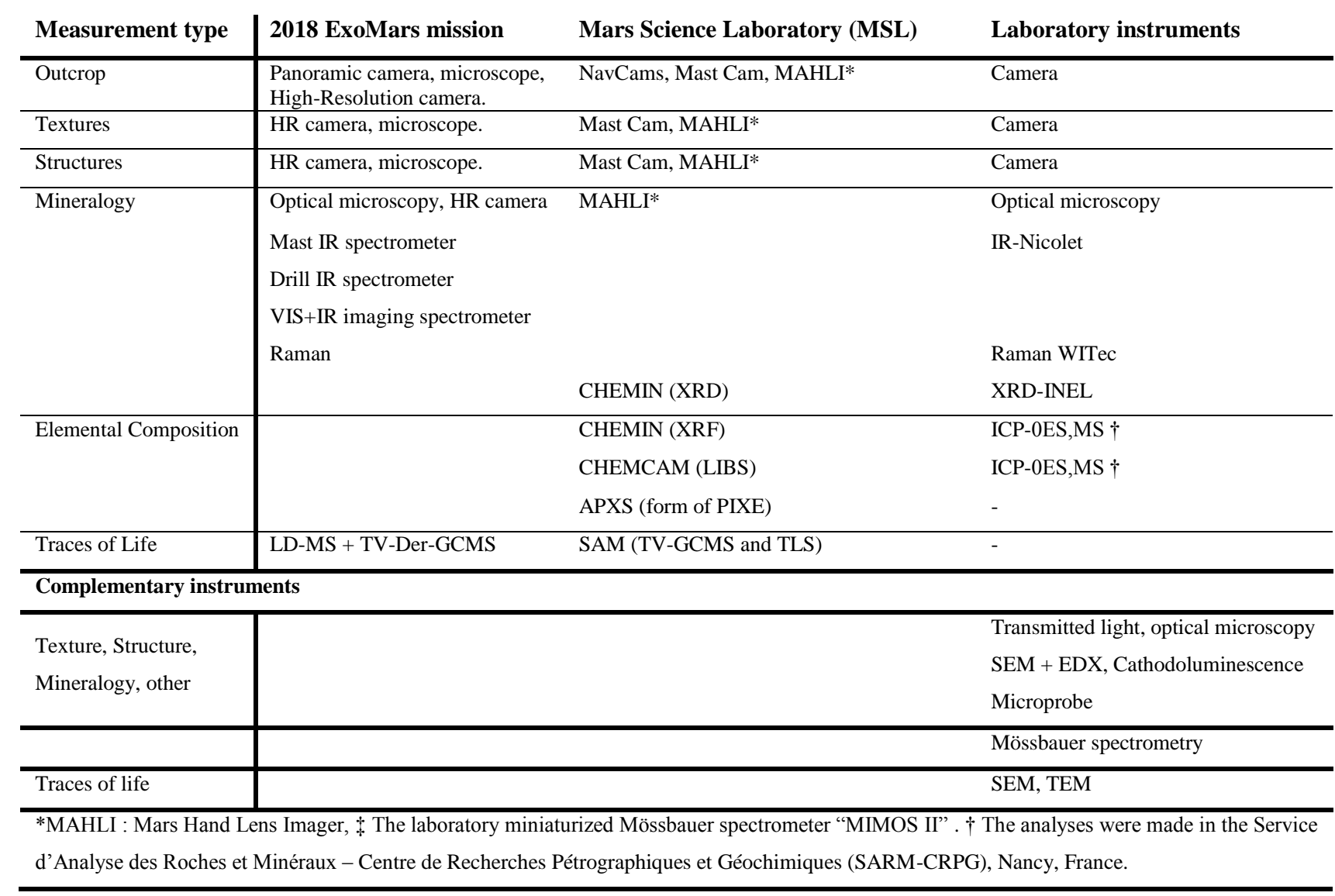


Table 2. List of the analogue samples characterised for the ISAR collection and their proposed Martian equivalents.

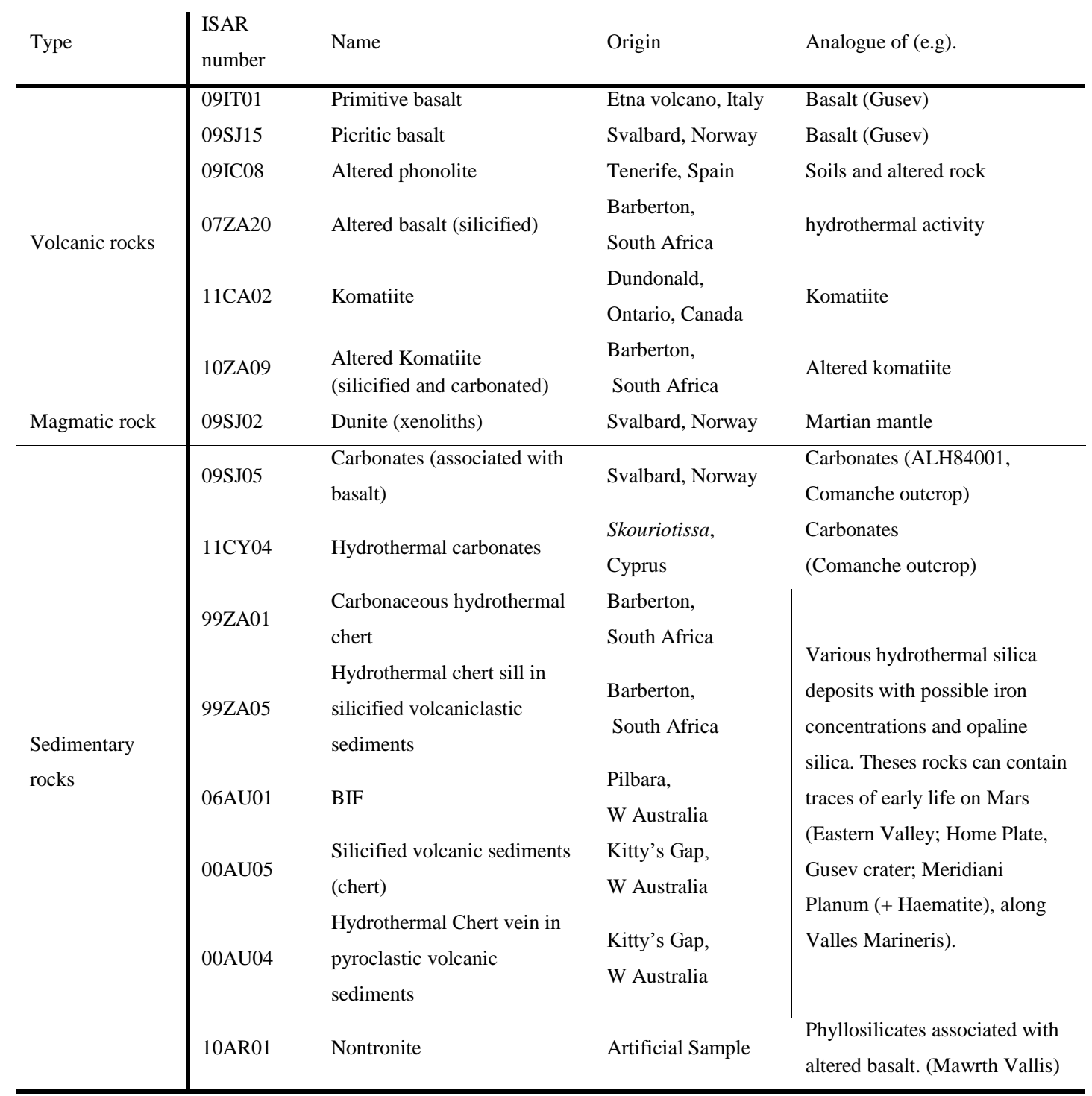


Table 3. Electron microprobe elemental analyses of major minerals in the ISAR volcanic and igneous samples. The measurements were obtained with the Cameca SX50 from ISTO-

BRGM at Orléans.

\begin{tabular}{|c|c|c|c|c|c|c|c|c|c|c|c|c|}
\hline Sample & $\begin{array}{l}\text { Elem } \\
\mathrm{K}_{2} \mathrm{O}\end{array}$ & $\begin{array}{l}\text { nts wt. } 9 \\
\mathrm{SiO}_{2}\end{array}$ & $\mathrm{FeO}$ & $\mathrm{CaO}$ & $\mathrm{Na}_{2} \mathrm{O}$ & TiO2 & $\mathbf{A l}_{2} \mathbf{O}_{3}$ & MnO & $\mathrm{Cr}_{2} \mathrm{O}_{3}$ & MgO & Cl & $\mathbf{P}_{2} \mathbf{O}_{5}$ \\
\hline $\begin{array}{l}\text { 09IT01 } \\
\text { Olivine }\end{array}$ & 0.024 & 41.228 & 9.166 & 0.256 & 0.034 & 0 & 0.021 & 0.071 & 0.044 & 51.158 & 0 & 0.05 \\
\hline $\begin{array}{l}\text { Diopside } \\
\text { 09SJ15 }\end{array}$ & 1.180 & 48.307 & 10.283 & 15.198 & 1.709 & 1.304 & 12.032 & 0.052 & 0.015 & 9.025 & 0.113 & 0.428 \\
\hline Olivine & 0.028 & 40.071 & 15.094 & 0.242 & 0.003 & 0.003 & 0.06 & 0.08 & 0.092 & 46.088 & 0 & 0.105 \\
\hline Pyroxene & 4.667 & 49.478 & 6.984 & 4.628 & 7.19 & 2.198 & 19.025 & 0.182 & 0.026 & 2.225 & 0.205 & 1.015 \\
\hline $\begin{array}{l}\text { Plagioclase } \\
091 \mathrm{C} 08\end{array}$ & 0.088 & 42.159 & 8.459 & 22.751 & 0.627 & 5.286 & 9.87 & 0.128 & 0.056 & 10.744 & 0 & 0.330 \\
\hline Amphibole & 0 & 51.692 & 8.81 & 22.097 & 0.985 & 0.911 & 1.931 & 0.612 & 0 & 13.654 & 0 & 0.222 \\
\hline Plagioclase & 3.084 & 61.372 & 0.549 & 3.011 & 7.759 & 0.078 & 20.419 & 0.105 & 0 & 0.472 & 0 & 0.066 \\
\hline $\begin{array}{l}\text { Apatite } \\
\text { 07ZA20 }\end{array}$ & 0 & 0.528 & 0.265 & 54.161 & 0.163 & 0 & 0.015 & 0.056 & 0 & 0.023 & 0.238 & 41.14 \\
\hline Plagioclase & 0.142 & 62.024 & 5.32 & 3.394 & 7.838 & 0.095 & 14.651 & 0.046 & 0.028 & 2.809 & 0.026 & 0.167 \\
\hline Pyroxene & 0.364 & 49.597 & 11.571 & 4.412 & 4.866 & 2.178 & 15.008 & 0.259 & 0 & 4.571 & 0.013 & 0.071 \\
\hline $\begin{array}{l}\text { 11CA02 } \\
\text { Amphibole }\end{array}$ & 0.001 & 48.322 & 8.115 & 17.105 & 0.158 & 0.387 & 6.052 & 0.018 & 0.386 & 16.073 & 0.012 & 0.147 \\
\hline Clays & 0.166 & 32.562 & 10.84 & 0.064 & 0.137 & 0.023 & 12.937 & 0.086 & 0.022 & 26.138 & 0.02 & 0.089 \\
\hline 10ZA09 & & & & & & & & & & & & \\
\hline Pyroxene & 0.045 & 52.46 & 8.457 & 10.611 & 0.732 & 0.369 & 3.803 & - & 0.668 & 20.756 & 0.013 & 0.149 \\
\hline $\begin{array}{l}\text { Clays } \\
\text { 09SJ02 }\end{array}$ & 0.004 & 44.405 & 10.526 & 0.204 & 0.069 & 0.06 & 1.047 & - & 0.123 & 20.756 & 0 & 0 \\
\hline Enstatite & 0 & 56.137 & 6.579 & 0.168 & 0.093 & 0.098 & 3.520 & 0.143 & 0.197 & 34.833 & - & 0 \\
\hline Olivine & 0 & 40.711 & 10.262 & 0.003 & 0 & 0.005 & 0 & 0.125 & 0.05 & 1.002 & - & 0 \\
\hline
\end{tabular}


Table 4. Comparison of textural, elemental and mineralogical data from the volcanic and magmatic rocks using different instruments and different sample preparations. (++) unambiguous identification, $(+)$ probably identification, (-) identification ambiguous, (--) identification impossible. Macro.: Macroscopic view, Micro.: Microscopic view, P.: Powder, W.S. : Weathered surface, T.S.: Thin section - * only Raman spectrum- The hatched area indicates that the measurement is not applicable for a specific instrument.

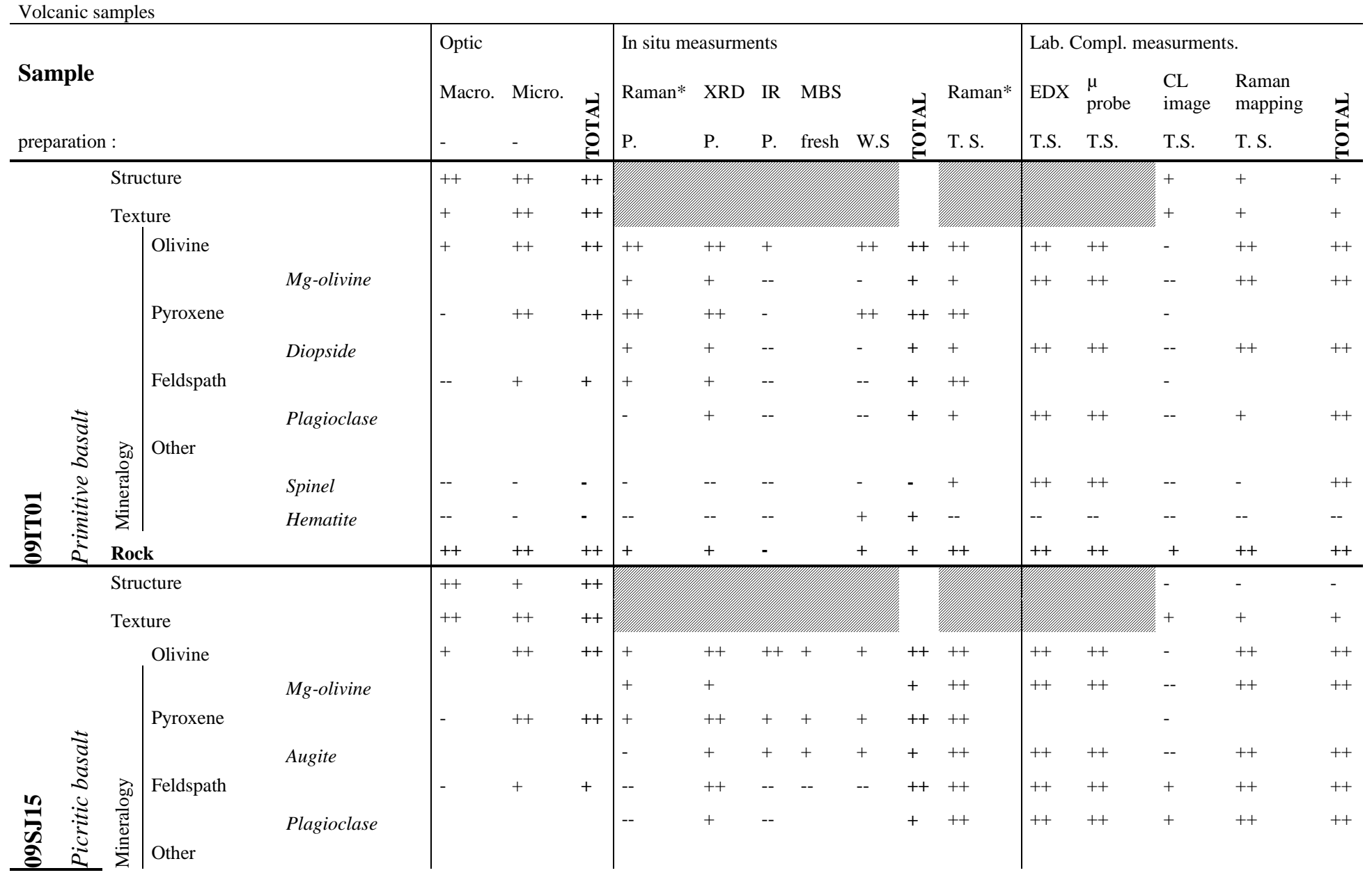




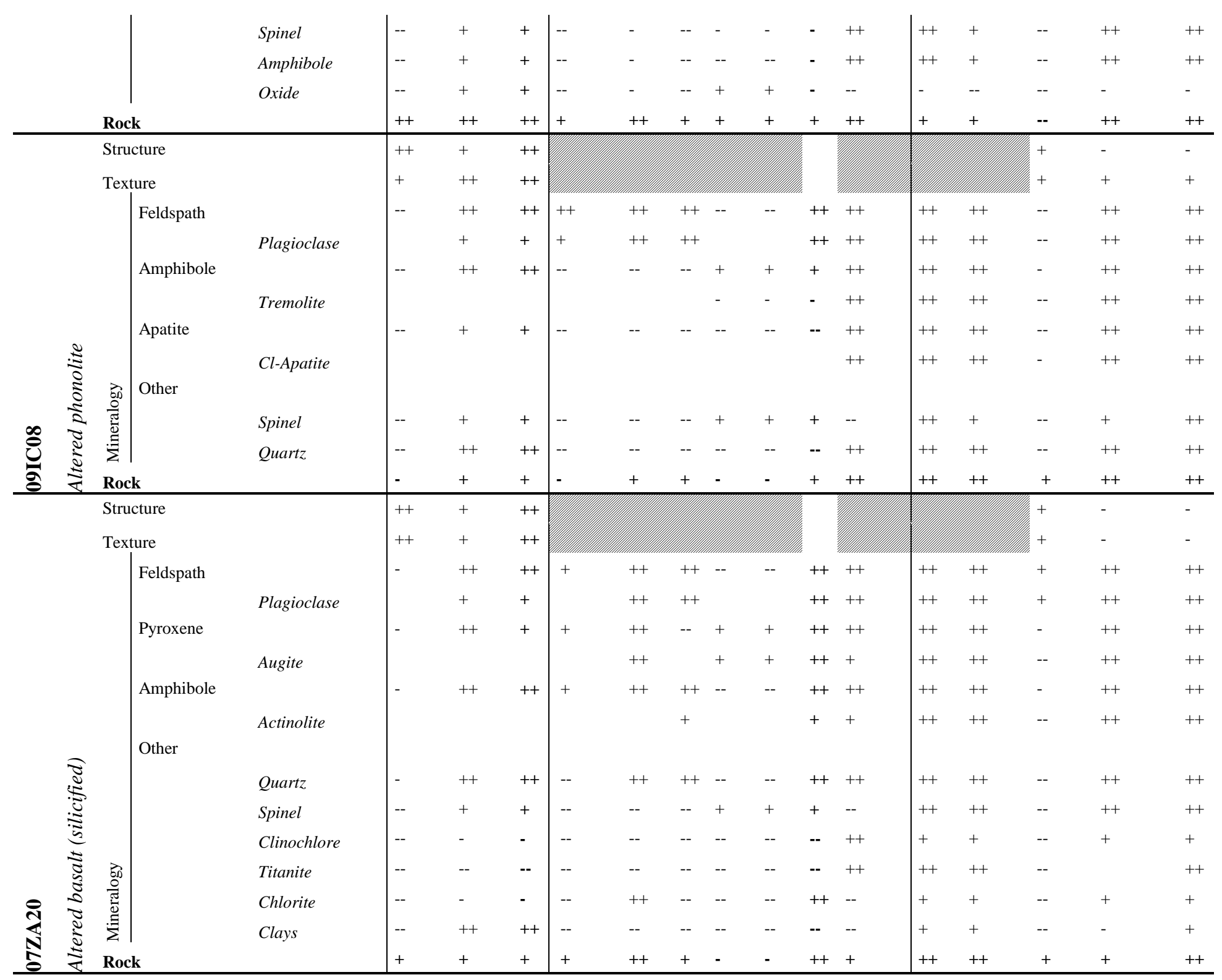




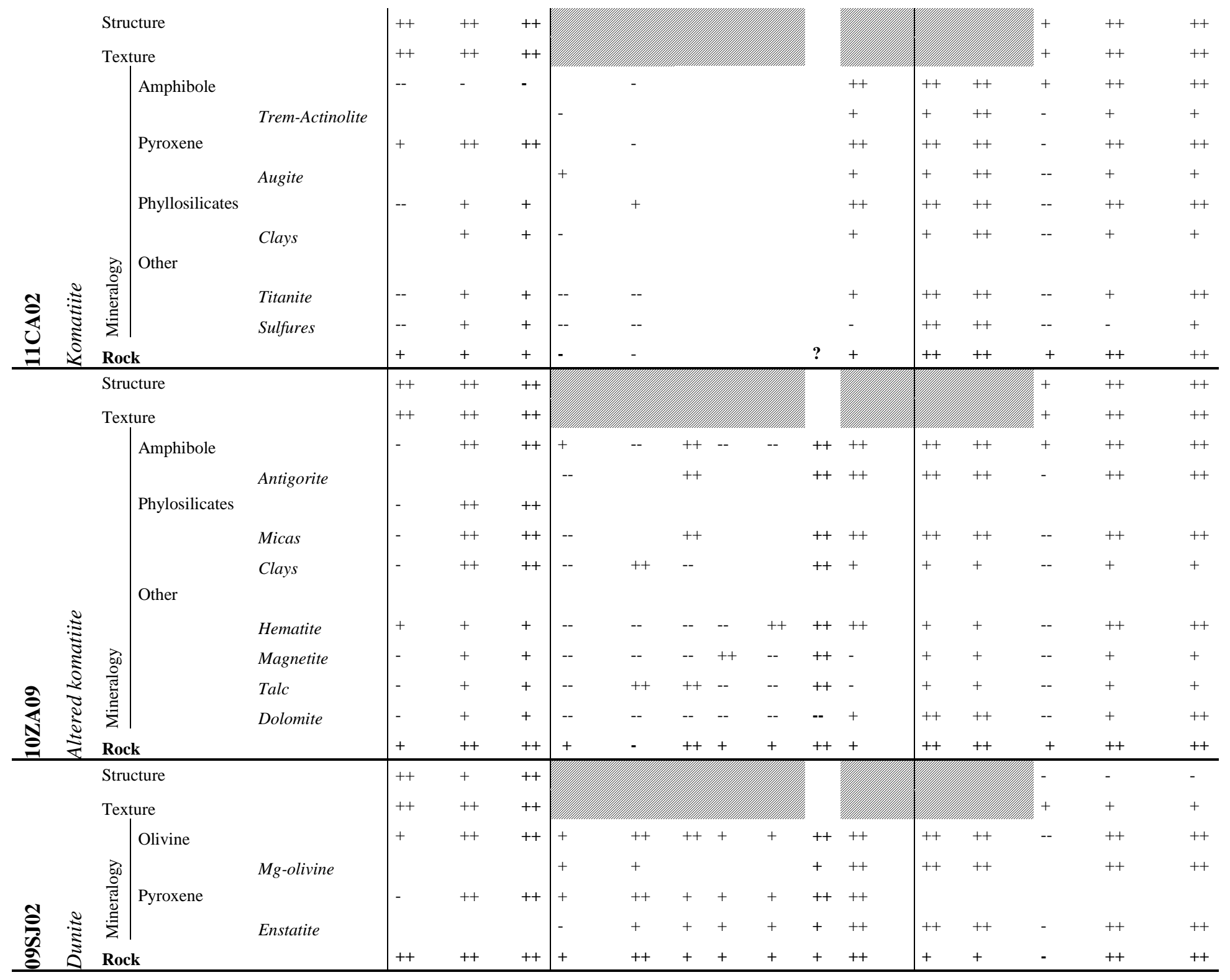


Table 5 . Comparison of textural, elemental and mineralogical data from the sedimentary rocks and minerals using different instruments and different sample preparations. (++) unambiguous identification, (+) probably identification, (-) identification ambiguous, (--) identification impossible. Macro.: Macroscopic view, Micro.: Microscopic view, P.: Powder, W.S. : Weathered surface, T.S.: Thin section - * only Raman spectrum- The hatched area indicates that the measurement is not applicable for a specific instrument.

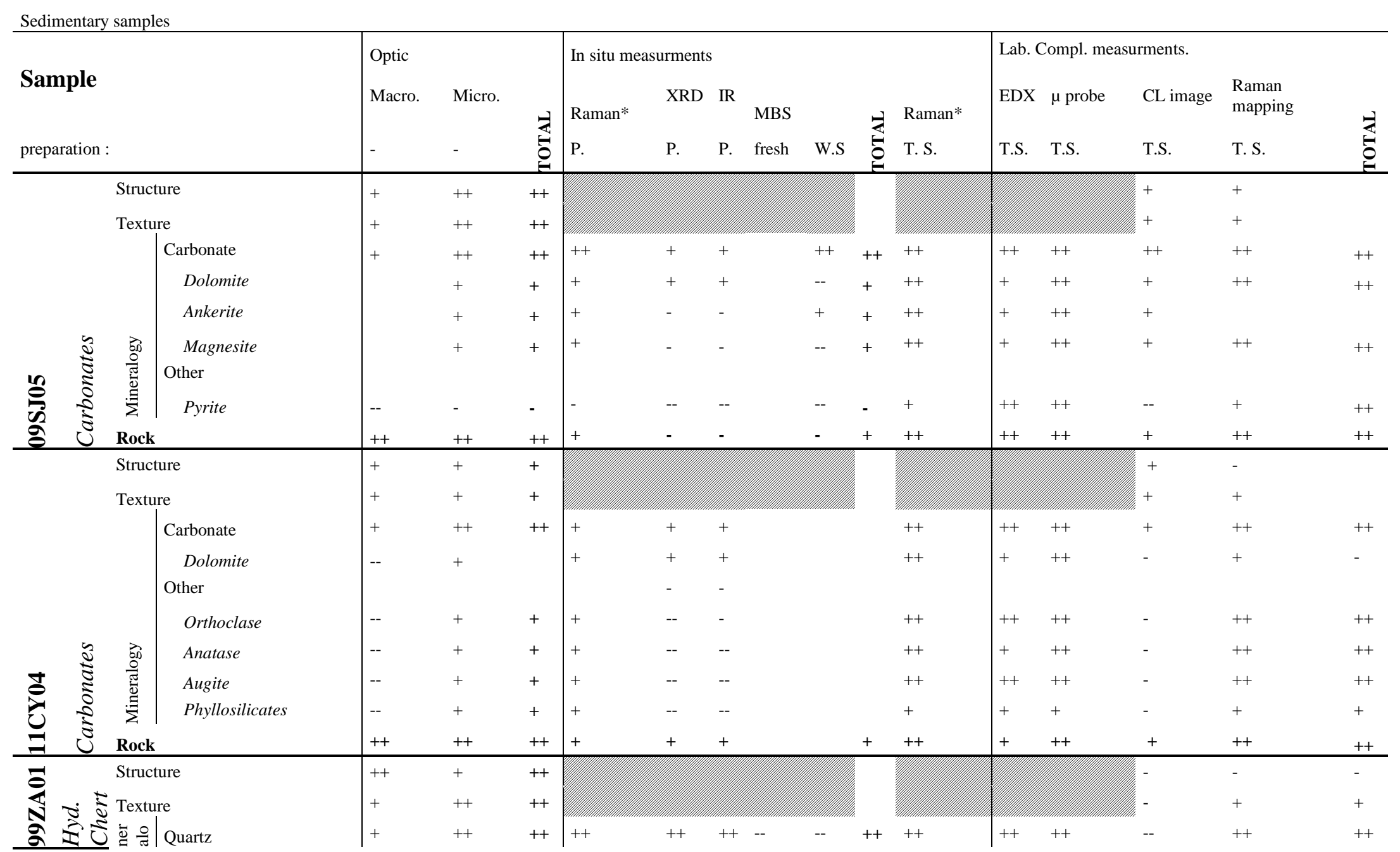




\begin{tabular}{|c|c|c|c|c|c|c|c|c|c|c|c|c|c|c|c|c|c|c|}
\hline & & & $\begin{array}{c}\text { Carbonaceous } \\
\text {-matter }\end{array}$ & $\begin{array}{l}-- \\
+\end{array}$ & $\begin{array}{l}++ \\
++\end{array}$ & $\begin{array}{l}++ \\
++\end{array}$ & -- & -- & -- & -- & -- & -- & $\begin{array}{l}+ \\
++\end{array}$ & & & -- & $\begin{array}{l}++ \\
++\end{array}$ & $\begin{array}{l}++ \\
++\end{array}$ \\
\hline \multicolumn{4}{|c|}{ Rock } & ++ & ++ & ++ & - & + & + & -- & -- & + & ++ & ++ & ++ & - & ++ & ++ \\
\hline \multicolumn{4}{|c|}{ Structure } & ++ & + & ++ & & & & & & & & & & - & + & + \\
\hline \multirow{5}{*}{ 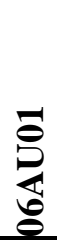 } & \multicolumn{3}{|c|}{ Texture } & ++ & + & ++ & & & & & & & & & & - & + & + \\
\hline & \multirow{4}{*}{ i: } & \multirow{4}{*}{$\underset{\text { Rock }}{\stackrel{\Xi}{\Xi}}$} & \multirow{4}{*}{$\begin{array}{l}\text { Quartz } \\
\text { Hematite } \\
\text { Goethite }\end{array}$} & ++ & ++ & ++ & ++ & ++ & ++ & -- & -- & ++ & ++ & ++ & ++ & -- & ++ & ++ \\
\hline & & & & - & + & + & - & + & -- & ++ & ++ & ++ & ++ & + & + & -- & ++ & ++ \\
\hline & & & & - & + & ++ & - & + & -- & ++ & ++ & ++ & ++ & + & + & -- & ++ & ++ \\
\hline & & & & + & + & + & & ++ & + & + & + & ++ & ++ & ++ & ++ & - & + & ++ \\
\hline \multirow{8}{*}{ 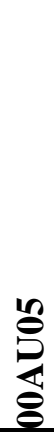 } & \multicolumn{3}{|c|}{ Structure } & ++ & ++ & ++ & & & & & & & & & & - & + & + \\
\hline & \multirow{7}{*}{ 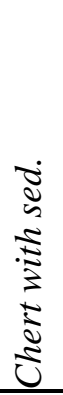 } & \multicolumn{2}{|c|}{ Texture } & ++ & ++ & ++ & & & & & & & & & & - & + & + \\
\hline & & \multirow{6}{*}{ 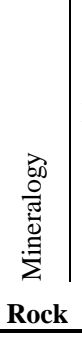 } & Quartz & ++ & ++ & - & ++ & ++ & ++ & & & ++ & ++ & ++ & ++ & -- & ++ & ++ \\
\hline & & & microcrystaline & & ++ & & & & & & & & + & + & & -- & ++ & ++ \\
\hline & & & Phylosilicates & -- & + & ++ & - & -- & -- & & & - & ++ & ++ & + & -- & ++ & ++ \\
\hline & & & $\begin{array}{l}\text { Hudromuscovite } \\
\text { Other }\end{array}$ & & - & & & & & & & & + & + & & -- & + & + \\
\hline & & & Ti-oxide & -- & - & + & - & -- & -- & & & & + & ++ & ++ & -- & ++ & ++ \\
\hline & & & & ++ & ++ & + & + & + & + & & & ++ & + & ++ & ++ & - & ++ & ++ \\
\hline \multirow{6}{*}{$\begin{array}{l} \pm \\
8 \\
8 \\
8\end{array}$} & \multirow{6}{*}{ 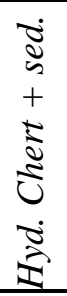 } & \multirow{2}{*}{\multicolumn{2}{|c|}{$\begin{array}{l}\text { Structure } \\
\text { Texture }\end{array}$}} & ++ & ++ & ++ & & & 8 & & & & & & & - & ++ & ++ \\
\hline & & & & ++ & ++ & ++ & & & & & & & & & & - & ++ & ++ \\
\hline & & & Quartz & ++ & ++ & ++ & ++ & ++ & ++ & & & ++ & ++ & ++ & ++ & -- & ++ & ++ \\
\hline & & $\dot{\Xi}$ & Other & & & & & & & & & & & & & & & \\
\hline & & $\dot{\Sigma}$ & Anatase & -- & + & + & + & -- & -- & & & + & ++ & ++ & ++ & -- & ++ & ++ \\
\hline & & \multicolumn{2}{|c|}{ Rock } & + & ++ & ++ & + & ++ & ++ & & & ++ & ++ & ++ & ++ & - & ++ & ++ \\
\hline \multirow{3}{*}{$\underset{\theta}{\theta}$} & \multirow{3}{*}{ 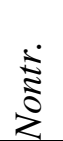 } & \multirow{3}{*}{\multicolumn{2}{|c|}{$\begin{array}{l}\text { Structure } \\
\text { Texture } \\
\text { Mineral }\end{array}$}} & & & & & & & & & & & & & & & \\
\hline & & & & & & & & & & & & & & & & & & \\
\hline & & & & -- & -- & ++ & -- & ++ & ++ & ++ & & ++ & & & & & & \\
\hline
\end{tabular}


